\title{
Geochemistry of El-Salam Canal and the adjacent groundwater in north Sinai, Egypt: an application to a water treatment process using magnetic zeolite nanoparticles
}

\author{
Thanaa Shalaby ${ }^{1} \cdot$ Mustafa Eissa $^{2}$ (D) Marwa El Kady ${ }^{3} \cdot$ Suzan Abd El-Gaber ${ }^{1}$
}

Received: 9 June 2017 / Accepted: 4 June 2018 / Published online: 23 June 2018

(C) The Author(s) 2018

\begin{abstract}
Water shortage is among the critical challenges facing many countries located in the arid zone of the southern the Mediterranean region. In the northern Sinai, El-Salam Canal and shallow groundwater in the Quaternary aquifer are considered the main irrigation sources for reclamation of 62,000 acres situated along the Mediterranean coast. The chemistry of surface water of El-Salam Canal varies greatly from the western to the eastern sides. Additionally, the groundwater chemistry is greatly influenced by dilution due to seepage of El-Salam Canal water. The historical and recent records of water chemistry show great variation of the concentrations of dissolved $\mathrm{Al}^{3+}, \mathrm{Cu}^{2+}$ and $\mathrm{Zn}^{2+}$ in both surface and groundwater, based on sampling time and locality. The concentrations of these heavy metals occasionally exceed the international recommended limits for drinking and short-term irrigation standards. The removal of dissolved heavy metals from water is crucial to fill the gap between the water supply and the growing demands using possible techniques of water treatment. Consequently, zeolite nanocomposites are one of the materials that have been used for water treatment. Magnetic zeolite nanocomposites (MZNCs) were prepared by the chemical co-precipitation of $\mathrm{Fe}^{2+}$ and $\mathrm{Fe}^{3+}$ in the presence of zeolite. The prepared magnetic nanocomposites were characterized by TEM, SEM, EDX, XRD, FTIR, TGA and VSM. The results show that MZNCs have a cubic crystal structure and good thermal stability. The MZNCs were used to remove $\mathrm{Al}(\mathrm{III}), \mathrm{Zn}$ (II) and $\mathrm{Cu}$ (II) from simulated water and then were easily separated from the medium by external permanent magnet. Batch adsorption experiments were conducted, and the effects of $\mathrm{pH}$, initial ion concentration, adsorbent dose and contact time were studied. The selected $\mathrm{pH}$ range $(\mathrm{pH}=5-6)$ and temperature $\left(27^{\circ} \mathrm{C}\right)$ in the batch adsorption experiments were close to the $\mathrm{pH}$ range of the surface and groundwater field data. Furthermore, the chosen initial concentrations and adsorbent doses were within the heavy metals concentration ranges in El-Salam Canal and the adjacent groundwater. The MZNCs show great removal capacity of heavy metals where $0.1 \mathrm{~g}$ is able to clean contaminated water with high concentrations $(0.5-3 \mathrm{~g} / \mathrm{l})$ of $\mathrm{Cu}(\mathrm{II})$ and $\mathrm{Zn}$ (II) within $20 \mathrm{~min}$ and within $30 \mathrm{~min}$ for $\mathrm{Al}(\mathrm{III})$. The adsorption kinetics data of the system were well fitted to pseudo-second-order model, which indicates a faster kinetic sorption by the composites. Adsorption isotherms were studied using Langmuir and Freundlich isotherms. Although both of them fit the data, the Freundlich isotherm had the best fit for the selected metals.
\end{abstract}

Keywords El-Salam Canal water $\cdot$ Hydrogeochemistry $\cdot$ Water treatment $\cdot$ Magnetic zeolite $\cdot$ Nanocomposite

\section{Introduction}

Electronic supplementary material The online version of this article (https://doi.org/10.1007/s13201-018-0741-7) contains supplementary material, which is available to authorized users.

Mustafa Eissa

mostafaa75@hotmail.com

Extended author information available on the last page of the article
Shortages of freshwater supplies are a result of the exploitation of water resources for domestic, industry and irrigation purposes in many parts of the world (Shannon et al. 2008). The needs of freshwater supplies due to the increasing world's demand of food, energy and so forth are increasing more and more due to population growth and threats of climate change (Godfray et al. 2010). Polluting surface/ groundwater sources is another cause of reduced freshwater supplies. 
This research aims to examine the distribution of heavy metals in surface and groundwater adjacent to El-Salam Canal as well as the possibility of heavy metals removal using the magnetic zeolite nanoparticles. It should be recognized that studying the variation of heavy metals and major constituents in surface and groundwater is necessary to determine the main pollutant sources that deteriorate water quality. The water salinity and the concentrations of aluminum, copper and zinc have shown great variation in the last decade, both in the surface water of El-Salam Canal and in the adjacent groundwater (Hafeza et al. 2008; Othman et al. 2012; El Sheikh et al. 2013). Additionally, the concentration of these heavy metals has increased with time in soil and plant samples close to El-Salam Canal (DRC 2009). El-Naggar et al. 2000; Abdel Baky (2001) also reported that the $\mathrm{Pb}, \mathrm{Cd}, \mathrm{Ni}, \mathrm{Cu}, \mathrm{Mn}, \mathrm{Zn}, \mathrm{Cr}$ and Fe levels were elevated in the aquatic fisheries. In order to monitor the water quality of El-Salam Canal and the adjacent groundwater, fifteen water samples representing both surface and groundwater were collected in December (2014) for analysis of salinity, major and heavy metals ( $\mathrm{Al}, \mathrm{Cu}$ and $\mathrm{Zn}$ ) using plasma optical emission mass spectrometer (ICP-OE-MS). El-Salam Canal water is a mixture of the Nile freshwater with agriculture drainage brackish water in a ratio about 1:1. As a result, the surface water of El-Salam Canal has appropriate salinity for irrigation (Fig. 1).
Heavy metals are elements having atomic weights between 63.5 and 200.6 and have a specific gravity greater than $5.0 \mathrm{~g} / \mathrm{cm}^{3}$ (Jaishankar et al. 2014). With the rapid development of industries such as metal plating facilities, mining operations, fertilizer industries, tanneries, batteries, paper industries and pesticides, heavy metals from wastewaters are directly or indirectly discharged into the environment, especially in developing countries. Unlike organic contaminants, heavy metals are not biodegradable and tend to accumulate in living organisms, and many heavy metal ions are known to be toxic or carcinogenic (Morais et al. 2012).

Bioaccumulation of heavy metals in food chains and their toxicity to biological systems due to increased concentration over time have led to tremendous pressure for their separation and purification. Faced with more and more stringent regulations, nowadays heavy metals are the environmental priority pollutants and are becoming one of the most serious environmental problems. Heavy metals should be removed from the wastewater to protect the people and the environment, with the treated water reused for irrigation purposes, specifically in arid countries. Many conventional methods that are being used to remove heavy metal ions include chemical precipitation, ion exchange, adsorption, membrane filtration and electrochemical treatment technologies (Parmar and Thakur 2013; Zamboulis et al. 2011).

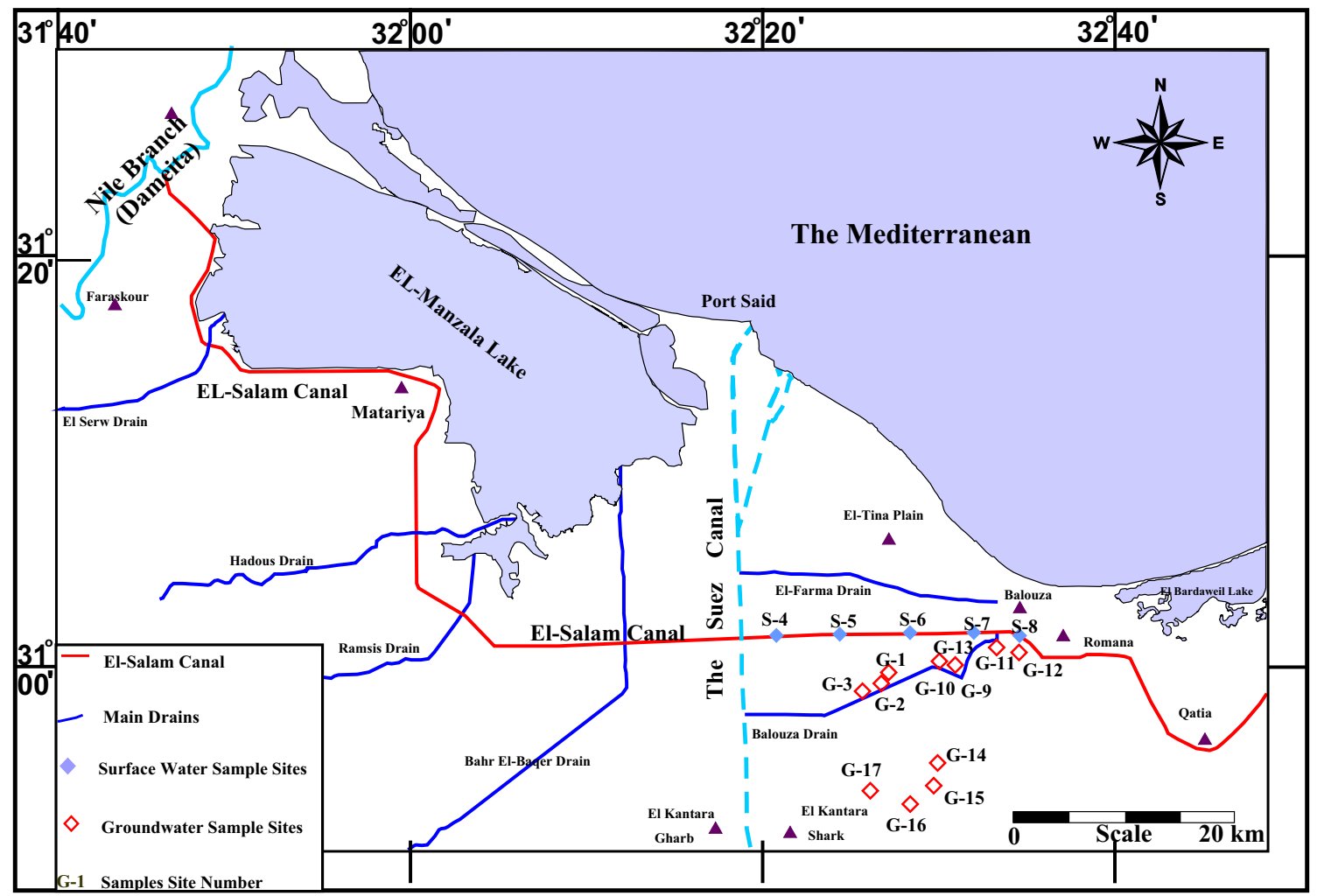

Fig. 1 Location sites of surface and groundwater samples along El-Salam Canal 
The development of efficient water treatment technology has become an important area of research as it offers a solution to the increasingly limited water supplies available to the world's growing population and industry. Nanotechnology is currently at the forefront of the latest research in water treatment and has been identified as a useful tool in resolving current problems in water treatment. Nanotechnology comprises the fabrication and functionality of materials with dimensions within the nanoscale $(1-100 \mathrm{~nm})$. Because of the larger surface area-to-volume ratio and smaller size, chemical and physical properties of the material are altered, giving it novel qualities (Hu and Apblett 2014).

Magnetic nanocomposites possess the advantages of large surface area, high number of surface active sites and high magnetic properties. These properties lead to high adsorption efficiency, high removal rate of contaminants, and easy and rapid separation of adsorbent from solution via magnetic field. In addition, it is possible that, after magnetic separation by the external magnetic field, the harmful components can be removed from the magnetic particles, which can be reused (Zhang 2003). The aim of the work is to prepare magnetic zeolite nanocomposites for adsorption of heavy metals. These nanocomposites were then subjected to El-Salam Canal water treatment to analyze their adsorption properties.

\section{Materials and methods}

\section{Water quality assessment}

Water samples were collected from twelve groundwater drilled wells and five surface water samples from El-Salam Canal in December 2014 (Fig. 1). The surface water samples were collected from the eastern side of the Suez Canal along $25 \mathrm{~km}$, with a distance interval of about $5 \mathrm{~km}$. The surface water samples were collected from the middle of the canal using Niskin water sampler model 60.100. The groundwater samples were collected using SP16 Geoprobe groundwater sampler. The depth to groundwater from the ground surface was measured using Solinst WLT Meter Model 201 (ESM 1). Samples were filtered in the field through a $0.45-\mu \mathrm{m}$ filter and collected in polyethylene bottles for both major, minor and trace chemical analyses. The pH (AD 11 Adwa model) and electrical conductivity (EC) were measured in the field. Electrical conductivity was measured with a YSI model 35 conductivity meter. The $\mathrm{pH}$ meter was calibrated once daily during the field campaign using 4, 7 and 10 standard solutions, while the EC meter was calibrated using 1000, 5000 and 10,000 ppm standard solutions. Major ion analyses were conducted at the Desert Research Center, Water Central Laboratory, in Cairo, Egypt, using the analytical methods described in Rainwater and Thatcher (1960) and Fishman and Friedman (1985). The total dissolved solids
(TDS in $\mathrm{mg} / \mathrm{l}$ ) were estimated using the equation described by Hem 1991, where the TDS $=\mathrm{Ca}^{2+}+\mathrm{Mg}^{2+}+\mathrm{Na}^{+}+\mathrm{K}^{+}+$ $\mathrm{Cl}^{-}+\mathrm{SO}_{4}{ }^{2-}+0.5\left(\mathrm{CO}_{3}{ }^{2-}+\mathrm{HCO}_{3}{ }^{-}\right)$. For quality assurance and quality control analysis, each sample was run in duplicate until standards were verified for each measurement, with the average value reported. The heavy metals, including aluminum, copper, iron, manganese and zinc $(\mathrm{Zn})$, were determined using an inductively coupled plasma-mass spectrometer (ICP-MS) TJA model (POEMS3) and $1000 \mathrm{ppm}$ (Merck) stock solution for standard preparation.

\section{Preparation of magnetic zeolite nanocomposite}

Ferrous chloride tetra hydrate $\left(\mathrm{FeCl}_{2} \cdot 4 \mathrm{H}_{2} \mathrm{O} \geq 99 \%\right)$ and ferric chloride hexahydrate $\left(\mathrm{FeCl}_{3} \cdot 6 \mathrm{H}_{2} \mathrm{O} \geq 99 \%\right)$ were purchased from Sigma-Aldrich Co. Sodium hydroxide $(\mathrm{NaOH})$ pellets, sodium aluminate and sodium meta-silicate were chemical grade. All glasswares were cleaned in aqua regia ( 3 parts $\mathrm{HCl}, 1$ part $\mathrm{HNO}_{3}$ ), rinsed with deionized water and then dried in the oven.

Zeolite was synthesized first according to the method represented by Smith et al. (1984) as follows: $25 \mathrm{~g}$ of sodium hydroxide and $13.5 \mathrm{~g}$ of sodium aluminate were dissolved in $300 \mathrm{ml}$ water, then stirred and boiled. The prepared solution was added to the hot solution of sodium meta-silicate (14.2 $\mathrm{g}$ in $200 \mathrm{ml}$ distilled water) under vigorous stirring. After hydrothermal crystallization, the product was washed with distilled water and dried overnight in an oven at $100^{\circ} \mathrm{C}$. MZNCs were prepared through the co-precipitation of $\mathrm{Fe}^{3+}$ and $\mathrm{Fe}^{2+}$ in the presence of zeolite. Aqueous solution of $\mathrm{FeCl}_{3}$ and $\mathrm{FeCl}_{2}$ salts was mixed and kept at $80{ }^{\circ} \mathrm{C}$ while maintaining a molar ratio of $\mathrm{Fe}^{2+} / \mathrm{Fe}^{3+}=1 / 2$. $\mathrm{NaOH}$ solution $(25 \% \mathrm{w} / \mathrm{v})$ containing zeolite was then added dropwise under vigorous mechanical stirring (1000 rpm) until black precipitate formed ( $\mathrm{pH} 10-11)$. The reaction system was kept at $80{ }^{\circ} \mathrm{C}$ for $6 \mathrm{~h}$ under vigorous stirring. Then, system was left to cool to room temperature, and the precipitates were separated by an external magnet and washed with doubly distilled water several times (Fig. 2). Finally, magnetic zeolite nanocomposites were washed with ethanol to facilitate the drying in a vacuum oven at $60-70{ }^{\circ} \mathrm{C}$ (Salah El-Din et al. 2011).

\section{Characterization of magnetic zeolite nanocomposite}

The physical size and shape of the prepared MZCs were determined by transmission electron microscope (TEM), JEOL-100 CX Model. The morphology and surface appearance of dried nanoparticles were examined by scanning electron microscope (SEM), Jeol, JSM-6360LA Model. Magnetic zeolite nanocomposites were characterized for the functional groups by FTIR spectrometer (Shimazdu IR Prestige-21) with a diffuse reflectance mode (DRS-8000) 
Fig. 2 Separation of MZN using an external stirred magnet
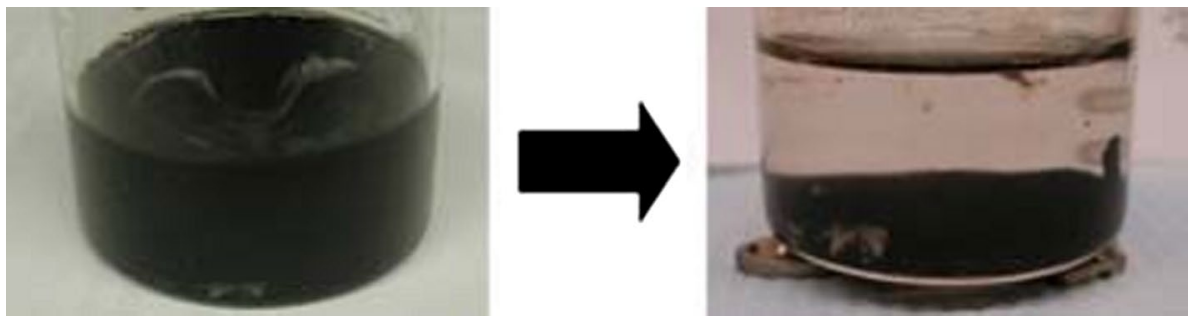

attachment. All measurements were taken in the range of $400-4000 \mathrm{~cm}^{-1}$ at a resolution of $4 \mathrm{~cm}^{-1}$. The crystalline nature of MZCs was taken by X-ray diffractometer (Shimaduz, XRD-7000, Maxima, Japan) operated at a voltage of $30 \mathrm{kV}$ and a current of $30 \mathrm{~mA}$ with $\mathrm{Cu} K_{\alpha}$ radiation $(=1.54 \AA)$ and analyzed between 5 and $100(2 \theta)$. Elemental composition of the nanocomposites was identified by EDX. Thermal property of MZCs was conducted on thermogravimetric analyzer (Shimadzu, TGA-50, Japan) with a heating rate of $20{ }^{\circ} \mathrm{C} / \mathrm{min}$ up to $600{ }^{\circ} \mathrm{C}$ under $\mathrm{N}_{2}$. The degree of magnetism of MZCs was evaluated using a vibrating sample magnetometer (VSM) (VSM-9600-1DSM-LDG-USA).

\section{Metal solutions}

Solutions of $\mathrm{Al}(\mathrm{III}), \mathrm{Cu}(\mathrm{II})$ and $\mathrm{Zn}(\mathrm{II})$ were prepared by dissolving predefined dried amounts of anhydrous $\mathrm{AlCl}_{3}$, $\mathrm{CuSO}_{4}$ and $\mathrm{Zn}\left(\mathrm{NO}_{3}\right)_{2}$ salts, respectively, in distilled water, in order to achieve stock solutions of 1000 ppm in each flask. Different initial concentrations of metal ions were prepared by diluting the stock solution.

\section{Adsorption process}

MZNCs were used for the adsorption of $\mathrm{Al}(\mathrm{III}), \mathrm{Cu}(\mathrm{II})$ and $\mathrm{Zn}$ (II) from an aqueous solutions using a batch technique at ambient temperatures. Adsorption processes were carried out in conical flasks put in a thermostatic water-bath shaker to adjust shaking at a fixed speed (200 rpm), until the equilibrium was reached. Fifty $\mathrm{ml}$ of aqueous solutions of $\mathrm{Al}(\mathrm{III}), \mathrm{Cu}$ (II) and $\mathrm{Zn}$ (II) at different initial concentrations $(100,70,50,30$ and $10 \mathrm{ppm})$ was transferred into $250-\mathrm{ml}$ conical flasks. Then, $0.1 \mathrm{~g}$ of MZNCs was added with continuous shaking at $200 \mathrm{rpm}$. The different parameters affecting adsorption process were studied.

\section{Effect of pH on adsorption process}

The $\mathrm{pH}$ is an important parameter in the adsorption of metal ions from aqueous solution. The adsorption of metal ions by magnetic zeolite nanocomposites was investigated in an initial $\mathrm{pH}$ range of $2-8$. The solution $\mathrm{pH}$ was adjusted using $0.1 \mathrm{~N}$ $\mathrm{NaOH}$ or $0.1 \mathrm{~N} \mathrm{HCL}$ and was measured using a $\mathrm{pH}$ meter (Horiba, Ltd. Kyoto, Japan). Adsorption process was done by adding $0.1 \mathrm{~g}$ of magnetic zeolite nanocomposites to $50 \mathrm{ml}$ of 100 ppm AL(III), Zn(II) and Cu(II) solutions contained in 250$\mathrm{ml}$ conical flasks. The flasks were placed in a thermostatic shaker and shaken at $200 \mathrm{rpm}$ for $24 \mathrm{~h}$. MZCs separation was performed by external permanent magnet. The metal concentrations in the supernatant were analyzed by ICP-MS.

\section{Effect of adsorbent mass on adsorption process}

The effect of adsorbent amount on removal efficiency of the metal ions was investigated using different doses of adsorbent in the range from 0.5 to $3 \mathrm{~g} / \mathrm{l}$, by adding different amounts of magnetic zeolite nanocomposites to $50 \mathrm{ml}$ of 100 ppm AL(III), Zn(II) and $\mathrm{Cu}$ (II) initial solution concentrations contained in $250-\mathrm{ml}$ conical flasks. The flasks were shaken at $200 \mathrm{rpm}$ shaking speed at $27{ }^{\circ} \mathrm{C}$, ambient $\mathrm{pH}$ for each metal and for adsorption time $24 \mathrm{~h}$. MZCs separation was performed by external permanent magnet. The metal concentrations in the supernatant were analyzed by ICP-MS.

\section{Effect of contact time and initial concentration}

A time-dependent batch experiment was conducted for the study of adsorption of $\mathrm{Al}(\mathrm{III}), \mathrm{Cu}$ (II) and $\mathrm{Zn}$ (II) using magnetic zeolite nanocomposites at $\mathrm{pH}=5$ for $\mathrm{Al}(\mathrm{III})$ and $\mathrm{pH}=6$ for $\mathrm{Cu}(\mathrm{II})$ and $\mathrm{Zn}$ (II) solution as follows: stock solution from $\mathrm{Al}(\mathrm{III}), \mathrm{Cu}(\mathrm{II})$ and $\mathrm{Zn}$ (II) with concentration $1000 \mathrm{mg} / \mathrm{l}$ was prepared from aluminum chloride, copper sulfate and zinc nitrate salts, respectively. Series concentrations (100, 70, 50, $30,10 \mathrm{ppm}$ ) were prepared for each metal ion; then, $0.1 \mathrm{~g}$ of dried magnetic zeolite nanocomposite was added to a $50 \mathrm{ml}$ metal ion solution in 250-ml conical flasks. The solution was stirred with a magnetic stirrer operated at $200 \mathrm{rpm}$ at $27^{\circ} \mathrm{C}$. At predetermined time intervals $(5 \mathrm{~min}$ at first then each $30 \mathrm{~min}$ ), the magnetic zeolite nanocomposites were magnetically separated from the aqueous solution, and $5 \mathrm{ml}$ samples were taken from the reactor for metal measurements using an ICP-MS. The metal concentration retained in the sorbent phase $\left(\mathrm{q}_{\mathrm{e}}, \mathrm{mg} / \mathrm{g}\right)$ was calculated from the following equation:

$q_{t}=\frac{c_{\mathrm{i}}-c_{\mathrm{e}}}{m}$

where $q$ is the adsorbent phase concentration after equilibrium(mg metal ion/g adsorbent), $C_{\mathrm{i}}$ and $C_{\mathrm{e}}$ are the 
initial and equilibrium concentrations of metal ion in solution ( $\mathrm{mg} / \mathrm{l}), V$ is the solution volume (l) and $m$ is the sorbent mass $(\mathrm{g})$. The percent removal of metal ions was calculated using the following equation:

$\%$ Removal $=\frac{c_{\mathrm{i}}-c_{\mathrm{e}}}{c_{\mathrm{i}}} \times 100$

\section{Adsorption kinetics}

For kinetic study, pseudo-first-order (PFO) and pseudo-second-order (PSO) equations were applied in order to determine the contact time required to reach equilibrium. The PFO model describes the rate of adsorption as to the number of unoccupied sites by the solutes and can be expressed by using the simple Lagergren equation (Lagergren 1898):

$\log \left(q_{e}-q_{t}\right)=\log q_{e}-k_{1} t$

where $q_{e}$ and $q_{t}(\mathrm{mg} / \mathrm{g})$ are the adsorbent phase concentrations at equilibrium and at time $t$, respectively, and $k_{1}$ $\left(\mathrm{min}^{-1}\right)$ is the rate constant of the pseudo-first-order adsorption (Lagergren 1898). The PSO model is expressed by the equation of Ho and McKay (1999) as:

$\frac{t}{q_{t}}=\frac{1}{k_{2} q_{e}^{2}}+\frac{t}{q_{e}}$

where $k_{2}\left(\mathrm{~g} \mathrm{mg}^{-1} \mathrm{~min}^{-1}\right)$ is the rate constant of the pseudosecond-order adsorption. The chemisorptions are usually regarded as the rate determining step for adsorption processes following pseudo-second-order kinetics (Ho and McKay 1999).

\section{Adsorption isotherms}

Adsorption equilibrium models of Langmuir and Freundlich were applied to determine the relationship of metals adsorption with different induced concentrations. The best-fitting isotherm was evaluated by linear regression, and the parameters obtained from the intercept and slope of the linear plots of these models. The generalized form of the Langmuir isotherm is represented by the following equation:

$\frac{c_{e}}{q_{e}}=\frac{1}{q_{m} k_{l}}+\frac{c_{e}}{q_{m}}$

where $q_{e}(\mathrm{mg} / \mathrm{g})$ is the equilibrium metal ion concentration on the adsorbent, $c_{e}(\mathrm{mg} / \mathrm{l})$ is the equilibrium metal ion concentration in solution, $q_{m}(\mathrm{mg} / \mathrm{g})$ is the monolayer capacity of the adsorbent and $k_{l}(1 / \mathrm{mg})$ is the Langmuir adsorption constant.

The essential characteristic of the Langmuir isotherm can be seen by the dimensionless constant called equilibrium parameter, $R_{\mathrm{L}}$ from equation:
$R_{l}=\frac{1}{1+K_{l} c_{o}}$

where $K_{l}(1 / \mathrm{mg})$ is the Langmuir constant related to the energy of adsorption and $c_{o}(\mathrm{mg} / \mathrm{l})$ is the lowest initial concentration. The value of $R_{l}$ could indicate the shape of isotherm to be either unfavorable $\left(R_{l}>1\right)$ or linear $\left(R_{l}=1\right)$ or favorable $\left(0<R_{l}<1\right)$ or irreversible $\left(R_{l}=0\right)$ (Liu 2006).

Freundlich isotherm is expressed by the equation:

$\log q_{e}=\log k_{f}+\frac{1}{n} \log c_{e}$

where $q_{e}(\mathrm{mg} / \mathrm{g})$ is the equilibrium metal ion concentration on the adsorbent and $c_{e}(\mathrm{mg} / \mathrm{l})$ is the equilibrium metal ion concentration in solution. $k_{f}(1 / \mathrm{mg})$ and $n$ are the Freundlich constants that can be related to the adsorption capacity and the adsorption intensity, respectively (Quiñones and Guiochon 1996).

\section{Results and discussion}

\section{Water geochemistry}

To evaluate the water suitability for surface and groundwater adjacent to El-Salam Canal for potable uses, 17 water samples were collected. Five surface water samples were collected from El-Salam Canal, and twelve groundwater samples were collected from shallow drilled wells in December 2014 (SEM1, Fig. 1). The surface water samples were collected from the eastern side of the Suez Canal, along $25 \mathrm{~km}$ with a distance interval of about $5 \mathrm{~km}$.

El-Salam Canal is considered the main sustainable water resource for the area located western of Suez Canal and northern Sinai in general. The main feed source for El-Salam Canal is the Nile water from the Damietta branch with different mixing percentages from El-Serw and Hadous drains (Fig. 1). The total annual supply of the canal attains about 4.45 billion cubic meters, with 2.11 billion cubic meters from the Nile water, and the remainder mainly coming from Hadous drain (1.905 billion cubic meters) and El-Serw drain (0.435 billion cubic meters) (DRI 1993; Ahmed 2003; ElDegwi et al. 2004). Five surface water and twelve groundwater samples were collected along the El-Salam Canal in December 2014, where site locations were selected to cover the implemented studied area for evaluating the chemistry variations of El-Salam Canal and the adjacent groundwater. The surface water salinity ranges between $897 \mathrm{mg} / \mathrm{l}$ at site $\left(\mathrm{S}_{4}\right)$ close to the Suez Canal to $1847 \mathrm{mg} / \mathrm{l}$ at site $\left(\mathrm{S}_{8}\right)$ close to terminal end of the El-Salam Canal. The surface water shows slight changes in the groundwater salinity between site $\left(S_{4}\right)$ and site $\left(S_{7}\right)$ and abrupt changes in the groundwater 
salinity at site $\left(\mathrm{S}_{7}\right)$ and site $\left(\mathrm{S}_{8}\right)$, due to the impact of groundwater seepage toward the surface water of El-Salam Canal (Fig. 3). In Fig. 4, the Stiff diagram (Stiff 1951) displays the pattern of the major ion composition of surface water samples at the terminal of El-Salam Canal (S7 and S8), resembling the pattern of the adjacent groundwater samples $\left(\mathrm{G}_{9}\right.$, $\mathrm{G}_{10}$ and $\mathrm{G}_{11}$ ).

The groundwater in the study area mainly occurs in the Quaternary aquifer. This aquifer is considered one of the important water bearings in the north Sinai. The Quaternary aquifer consists mainly of loose sand with few clay intercalations, and the groundwater exists under unconfined conditions (Embaby and El-Barbary 2011). The depth to the groundwater varies from a couple of meters in the northwest to $28 \mathrm{~m}$ in the southeast. It is principally controlled by the surface topography, lithology and recharge. According to El Sheikh et al. 2013, the groundwater generally flows from the southeast to the northwest. The groundwater in the northwestern side of the study area is greatly affected and diluted by El-Salam Canal's surface water, where the groundwater sample sites located close to Baloza drain and El-Salam Canal's main channel (sites $\mathrm{G}_{1-3}$ and $\mathrm{G}_{10}$ ) have relatively low groundwater salinity. In Piper diagram (Piper 1953), all surface and groundwater samples have $\mathrm{Cl}-\mathrm{Na}$ water type. The groundwater samples were plotted between the surface water samples and the seawater. The results indicate dilution due to surface water seepage through the fractures in the cement lining layer of the canal (Morsy 2014) (Fig. 5a). Conversely, the groundwater samples located far away from the canal drainages network have relatively high salinity.

The diagram of US Salinity Laboratory Staff (1954) is widely used for the evaluation of water for irrigation purposes and consists of a plot of specific conductivity (in $\mu \mathrm{mhos} / \mathrm{cm}$ ), which is a function of the dissolved solids concentration against the sodium adsorption ratio (SAR) (Fig. 5b). The waters are divided into four classes on the basis of salinity, and four classes on the basis of SAR,

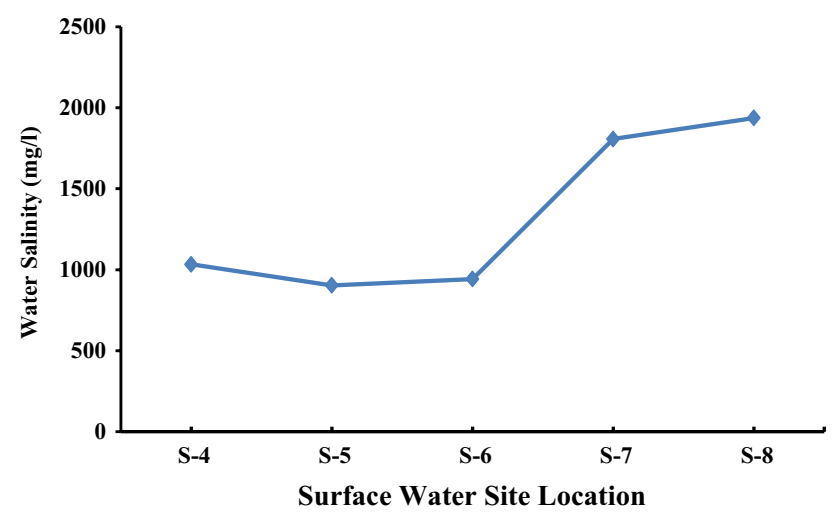

Fig. 3 The salinity of surface water samples along El-Salam Canal giving a total of sixteen possible quality classes. According to the US salinity diagram, it is clear that the majority of surface water samples are slightly suitable for irrigation purposes where plotted and are categorized as intermediate $\left(\mathrm{S}_{4}\right.$, $\mathrm{S}_{5}$ and $\mathrm{S}_{6}$ ) to bad water class $\left(\mathrm{S}_{7}\right.$ and $\left.\mathrm{S}_{8}\right)$. Only two groundwater samples $\left(G_{11}\right.$ and $\left.G_{12}\right)$ were evaluated as moderate water class for irrigation purposes, whereas other samples $\left(G_{3}, G_{9} G_{13}, G_{15-17}\right)$ were plotted in the upper right side of the US salinity diagram and were evaluated as intermediate to bad water class.

\section{Heavy metals}

The historical records of $\mathrm{Al}, \mathrm{Cu}$ and $\mathrm{Zn}$ show high concentrations in surface and groundwater samples according to Hassan el al. 2015 (Fig. 6). The concentration of heavy metal constituents in surface and groundwater samples collected in December 2014 is shown in Table 1 and is represented in Figs. 6 and 7. The concentration of aluminum in surface samples collected in December 2014 ranges between 0.15 and $0.72 \mathrm{mg} / \mathrm{l}$. In Figs. 6 and 7, the box plot and distribution maps show the $\mathrm{Al}$ concentrations exceeding the standard limits for human drinking $(0.2 \mathrm{mg} / \mathrm{l})$ and short-term irrigation $(5 \mathrm{mg} / \mathrm{l})$ in most of surface water samples $\left(\mathrm{S}_{4}, \mathrm{~S}_{5}, \mathrm{~S}_{6}\right.$ and $\left.\mathrm{S}_{7}\right) \mathrm{dpf}$ and many groundwater samples $\left(\mathrm{G}_{9}, \mathrm{G}_{12}, \mathrm{G}_{13}, \mathrm{G}_{14}\right.$, $\mathrm{G}_{16}$ and $\mathrm{G}_{17}$ ) as well (Table 2).

The copper concentrations are lower in both surface and groundwater samples collected in December 2014. However, some groundwater samples collected in 2012 (Hassan 2015) recorded copper concentrations higher than the recommended limits for the short-term irrigation standard $(0.2 \mathrm{mg} / \mathrm{l})$, according to the Australian guidelines for irrigation water quality (AWG 2012). Additionally, copper is considered as conservative element, as the copper concentration increasing with time in soil and plant samples, as well as aquatic fisheries close to El-Salam Canal (Abdel Baky 2001; DRC 2009); therefore, it has to be removed from water. In Fig. 6a, two groundwater samples $\left(\mathrm{G}_{3}\right.$ and $\left.\mathrm{G}_{16}\right)$ have $\mathrm{Zn}$ concentration marginal to the standard limits recommended for irrigation water (AWG 2012).

Most of groundwater and surface water samples ensure higher concentrations of aluminum, copper and zinc at different times, which influence the groundwater quality and potable uses suitability. Therefore, the efficiency of zeolite nanocomposite was investigated in order to be used for water treatment.

\section{Water treatment using magnetic zeolite}

\section{Characterization of nanocomposites}

Transmission electron microscope (TEM) The size and the morphology of MZNCs were determined by TEM (Fig. 8a). 

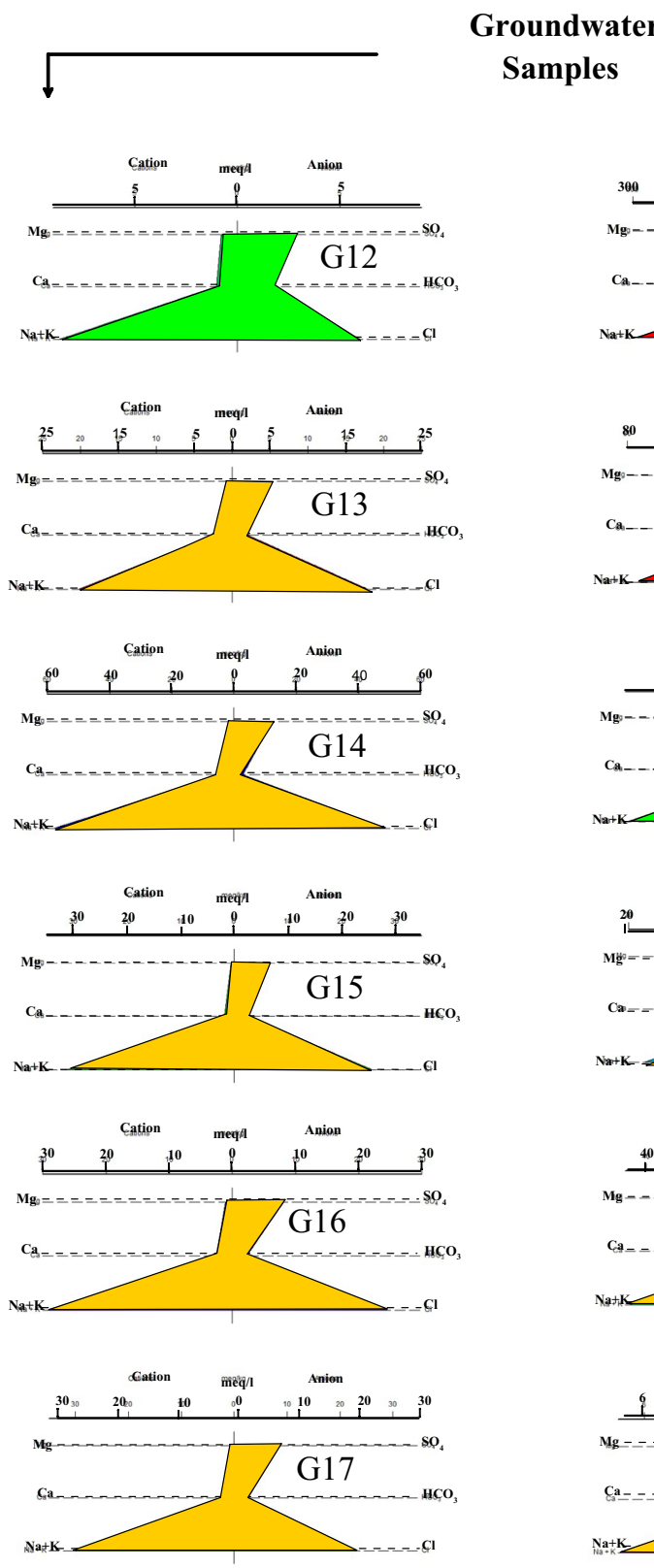
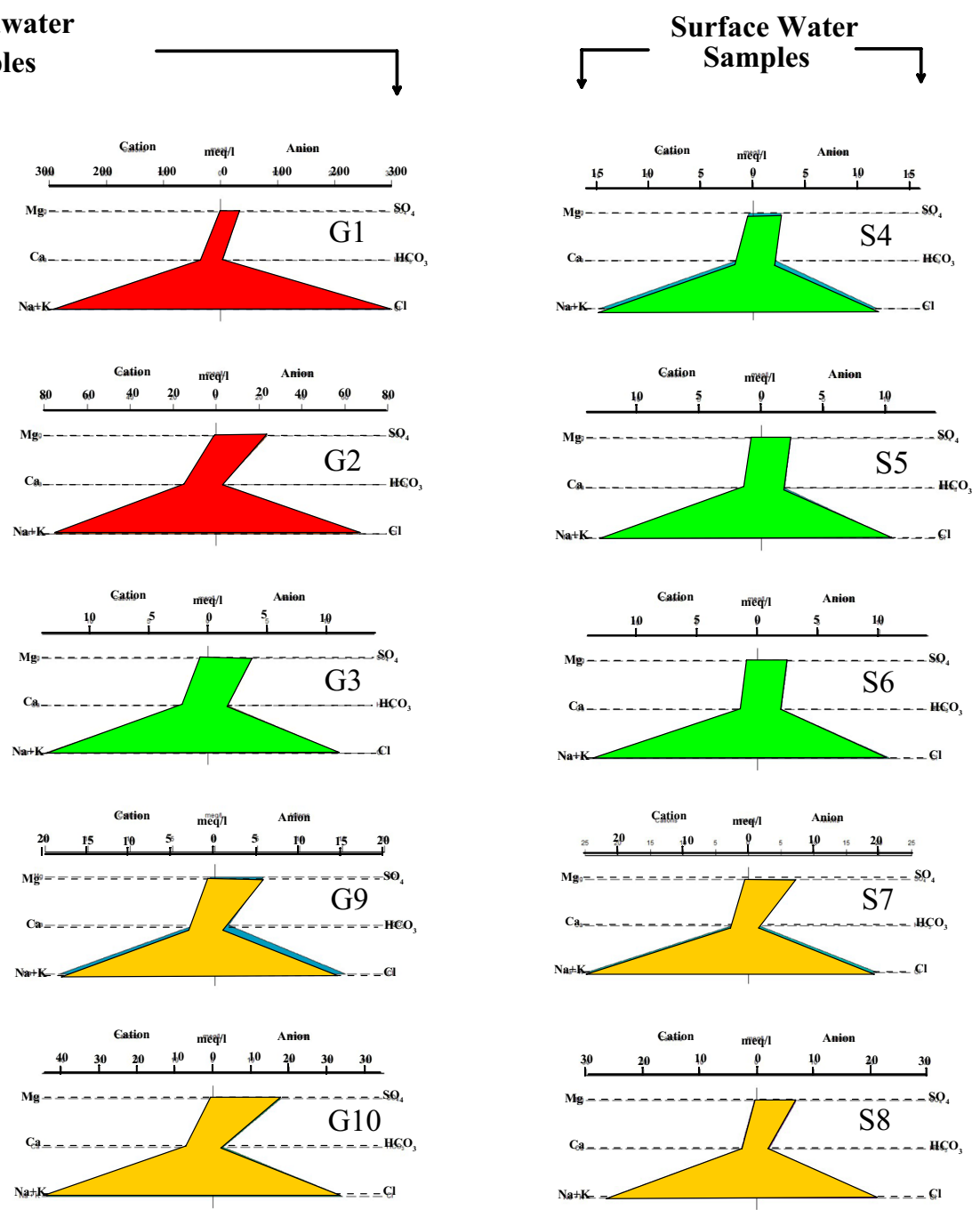

\section{Water Salinity Range}

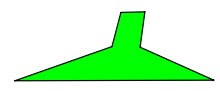

Less than $5000 \mathrm{mg} / \mathrm{l}$

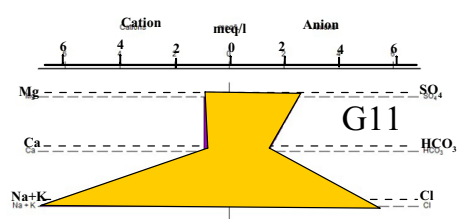

More than 10,000 mg/l

Fig. 4 Distribution of water salinity and Stiff diagram for surface water and groundwater samples collected in December 2014

TEM images showed that MZNCs were nanosize with average size $35 \mathrm{~nm}$ in which the zeolite NPs attached to MNPs. No monodispersion of nanoparticles was observed. Because of the high surface energy, MZNCs tend to form aggregates.
Scanning electron microscope and energy-dispersive X-ray analysis As shown in Fig. 8b, c, MZNCs are cubic in shape with the appearance of MNPs on the surface of zeolite NPs. The EDX spectrum of MZNCs shows that peaks at 0.55, $1.05,1.50$ and $1.75 \mathrm{keV}$ are related to the binding energies 

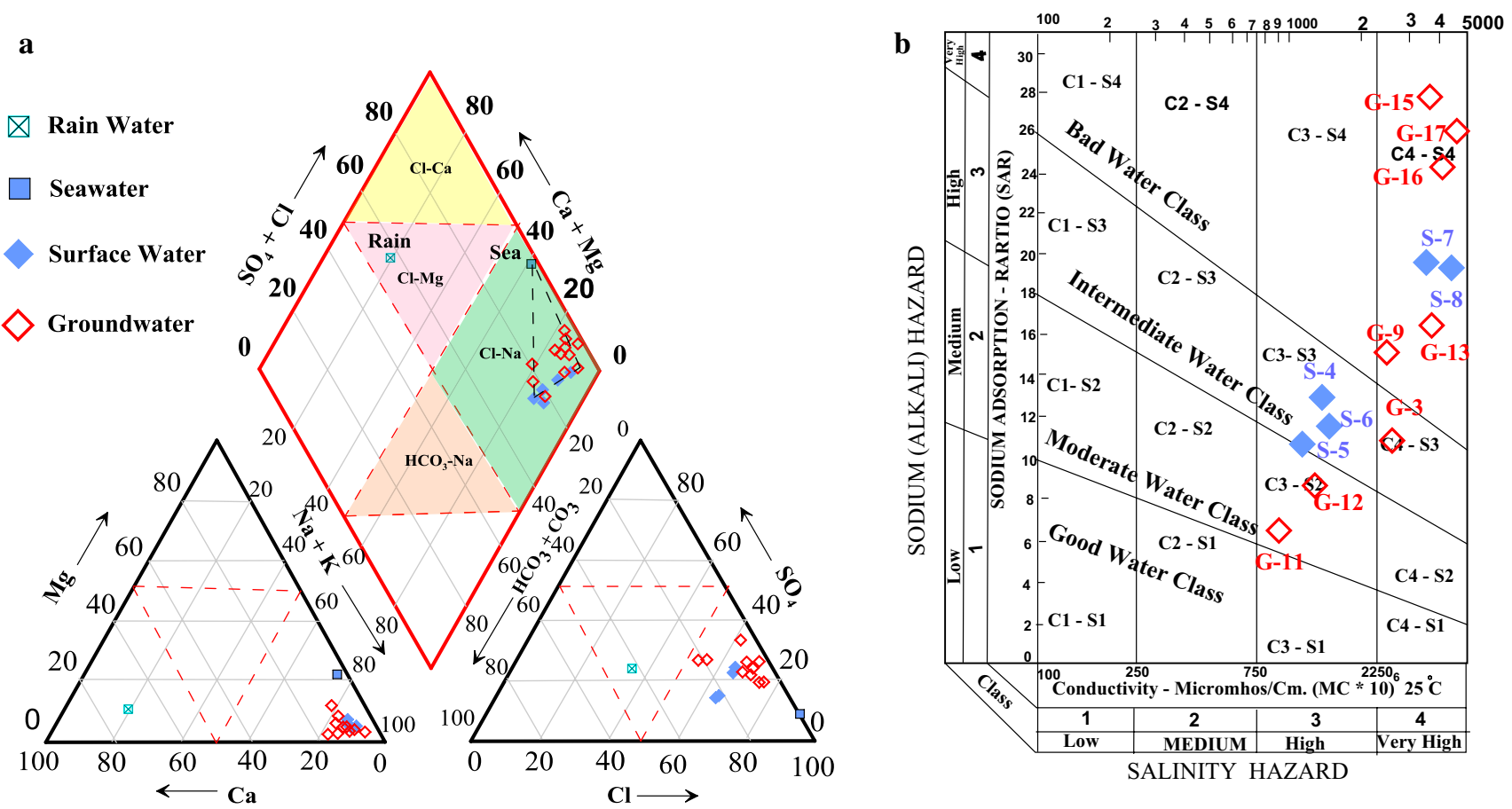

Fig. 5 a Piper diagram of the surface water and groundwater samples adjacent to El-Salam Canal. b The US salinity diagram for surface and groundwater adjacent to El-Salam Canal water

of $\mathrm{O}, \mathrm{Na}, \mathrm{Al}$ and $\mathrm{Si}$, respectively, which confirm the composition of zeolite plus peaks in regions of 6.4 and $7.05 \mathrm{keV}$, which are related to the binding energies of Fe. This confirms that the zeolite structure has not changed by synthesis of MZNCs. Moreover, the appearance of peaks in regions of $\mathrm{Fe}$ indicates the presence of iron in the products, well as incorporation of magnetic particles with high ratios into the prepared composite by our procedures of preparation.

X-ray diffractometer Figure 8d shows the XRD pattern of the MZNCs. The relative line intensity and line position related to zeolite at $2 \theta$ angle of $7.15^{\circ}, 10.15^{\circ}, 12.40^{\circ}, 21.65^{\circ}$, $23.95^{\circ}, 27.10^{\circ}$ and $29.90^{\circ}$ remained unchanged, indicating that during composite preparation, the crystal structure of zeolite was stable. The diffraction line of iron oxide was observed at $2 \theta$ of $30.1^{\circ}, 35.4^{\circ}, 43.2^{\circ}, 53.7^{\circ}, 57.1^{\circ}$ and $62.7^{\circ}$. Some reflection intensity peaks decreased with the formation of nanocomposite. In addition, there was a small shift of magnetite peaks to the higher diffraction angles, indicating the presence of $\mathrm{Fe}_{3} \mathrm{O}_{4}$ on the zeolite crystalline structure without changing the cubic structure shape.

XRD study revealed the crystal nature of MZNCs with cubic spinel structure. Figure 8d shows that the intensities of the peaks sample are relatively high as an indication of high crystallinity. The formed zeolite is a mixture of sodium aluminum silicate and sodium aluminum oxide silicates $(\mathrm{Si} /$ $\mathrm{Al}=1: 1$ ), which was confirmed by standard data for zeolite (ref's: 00-045-0437 and 01-076-0591). Also it was observed that the intensity of magnetite peaks decreased, during its presence in the nanocomposite as an indication of incorporation within pores of zeolite. This confirms that the structure of nanozeolite was not changed during composite preparation (Faghihian et al. 2014).

Fourier transform infrared spectroscopic analysis The FTIR spectrum of MZNCs was recorded between 400 and $4000 \mathrm{~cm}^{-1}$ (Fig. 8e). In the spectrum, the band observed at $547 \mathrm{~cm}^{-1}$ was assigned to $\mathrm{Fe}-\mathrm{O}-\mathrm{Fe}$ (Maity 2007). The bands at 444, 560 and $976 \mathrm{~cm}^{-1}$ were related to the vibration of $\mathrm{T}-\mathrm{O}$ bending, double ring and $\mathrm{TO} 4$ asymmetric stretch $(\mathrm{T}=\mathrm{Si}$ or $\mathrm{Al})$, respectively (Karge and Geidel 2004). The band at $3371 \mathrm{~cm}^{-1}$ represents inter and intermolecular hydrogen bonding. The adsorption band at $1648 \mathrm{~cm}^{-1}$ was related to interstitial bonded water. In the spectrum of the MZNCs sample, all the adsorption bands related to zeolite were observed and overlapped with the band related to $\mathrm{Fe}-\mathrm{O}-\mathrm{Fe}$, which may be attributed to incorporation of magnetite in the zeolite structure, hence supporting the doping of magnetite on the nanozeolite as available in the literature (Hidayat et al. 2015; Lateef et al. 2016).

Thermal gravimetric analysis (TGA) To determine the stability and thermal degradation pattern of prepared samples, TGA analysis was conducted. The TGA of MZNCs thermogram (Fig. 8f) was characterized by one single slope with continuous but smooth weight loss. The initial weight loss 

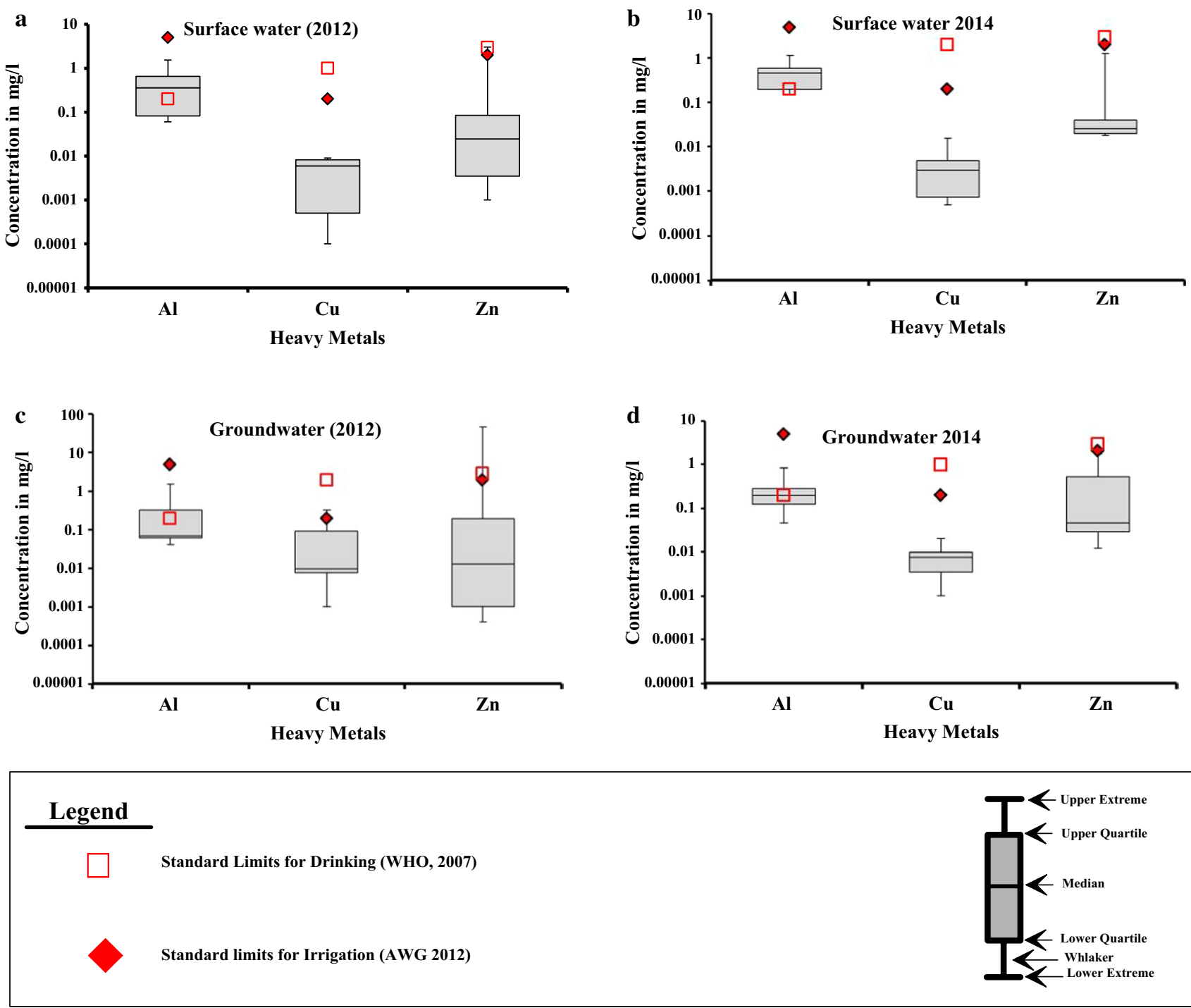

Fig. 6 Concentration $\mathrm{Al}(\mathrm{III}), \mathrm{Cu}(\mathrm{II})$ and $\mathrm{Zn}(\mathrm{II})$ in surface and groundwater adjacent to El-Salam Canal. The heavy metals concentration for surface and groundwater collected in 2012 is after (Hassan 2015)

(approximately accounts for weight loss of 4\%) occurring around $160{ }^{\circ} \mathrm{C}$ was attributed to dehydration as a result of water losses that physically adsorbed on the zeolite nanoparticles (Bonilla et al. 2009). This loss followed by further incremental minor decreases up to $600{ }^{\circ} \mathrm{C}$ because dihydroxylation proceeds (Musyoka et al. 2013). The total particles lost were only $10 \%$ weight which indicates thermal stability of MZNCs at higher temperatures which is often directly proportional to $\mathrm{Si}-\mathrm{Al}$ ratio (Usachev et al. 2003).

Vibrating sample magnetometer One of the most important features of MZNCs is its magnetic properties that were characterized with the VSM method. Vibrating sample magnetometer (VSM) will help to understand the magnetic properties of the prepared samples. Figure $8 \mathrm{~g}$ shows the magnetization curve of the composite. When the external MF intensity increased, the magnetization increased with saturation occurring at $18.304 \mathrm{emu} / \mathrm{g}$. By applying the reverse external MF, the magnetization achieved the reverse saturation. The hysteresis loop of the composite showed an $\mathrm{S}$-shaped curve with no remanence. Therefore, the MZNCs have good super-paramagnetic properties, and also when external MF is removed, the MZNCs can be redispersed quickly with shaking. The saturation magnetization value of magnetic zeolite was $18.304 \mathrm{emu} / \mathrm{g}$ which confirms that in practice, the composite can be easily separated with a permanent magnet. The figure explains the soft magnetic nature of formed MZNCs. 
Table 1 Heavy metal concentrations $(\mathrm{mg} / \mathrm{l})$ in surface and groundwater samples collected in December 2014

\begin{tabular}{llll}
\hline No. & $\mathrm{Al}$ & $\mathrm{Cu}$ & $\mathrm{Zn}$ \\
\hline G1 & 0.1262 & 0.006 & 0.5236 \\
G2 & 0.0459 & 0.005 & 0.0368 \\
G3 & 0.1785 & 0.0093 & 1.779 \\
G9 & 0.2675 & 0.001 & 0.0299 \\
G10 & 0.1206 & 0.007 & 0.1107 \\
G11 & 0.1235 & 0.003 & 0.023 \\
G12 & 0.2881 & 0.011 & 0.0526 \\
G13 & 0.2108 & 0.008 & 0.0288 \\
G14 & 0.2314 & 0.009 & 0.0418 \\
G15 & 0.1585 & 0.001 & 0.0122 \\
G16 & 0.8574 & 0.0204 & 1.473 \\
G17 & 0.6094 & 0.0103 & 0.517 \\
S4 & 0.4712 & 0.006 & 0.03 \\
S5 & 0.4639 & 0.003 & 0.05 \\
S6 & 0.7277 & 0.0005 & 0.022 \\
S7 & 0.2486 & 0.001 & 0.0261 \\
S8 & 0.1505 & 0.004 & 0.0184 \\
\hline
\end{tabular}

\section{Adsorption of metals using MZNCs}

Effect of $\mathrm{pH}$ on adsorption The effect of $\mathrm{pH}$ on $\mathrm{Al}$ (III), $\mathrm{Cu}(\mathrm{II})$ and $\mathrm{Zn}(\mathrm{II})$ adsorption using MZNCs was studied, as shown in Fig. 9a. The removal efficiency of $\mathrm{Cu}$ and $\mathrm{Zn}$ reaches the maximum at $\mathrm{pH}=6$ with 98.7 and $95.9 \%$, respectively, while, for $\mathrm{Al}(\mathrm{III})$ metal the removal efficiency reached the maximum at $\mathrm{pH}=5$ with $86.06 \%$.

Effect of adsorbent mass Figure $9 \mathrm{~b}$ shows the effect of MZNCs amount on the removal efficiency of $\mathrm{Al}(\mathrm{III}), \mathrm{Cu}$ (II) and $\mathrm{Zn}(\mathrm{II})$ in the range from 0.5 to $3 \mathrm{~g} / \mathrm{l}$ for the initial solutions concentration $100 \mathrm{ppm}$ at the ambient temperature and $\mathrm{pH}$. In our study, $0.1 \mathrm{~g} / 50 \mathrm{ml}(2 \mathrm{~g} / \mathrm{l})$ of MZNCs is considered as the optimum dose. The removal efficiency of different heavy metals was evaluated in the batch experiments using wide ranges of $\mathrm{pH}(2-8)$ and initial concentrations of $\mathrm{Al}$ and $\mathrm{Zn}$ and $\mathrm{Cu}(0.002-0.15 \mathrm{~g})$ at $27{ }^{\circ} \mathrm{C}$. The $\mathrm{pH}$ and concentration ranges of, $\mathrm{Al}, \mathrm{Zn}$ and $\mathrm{Cu}$ measured in the surface

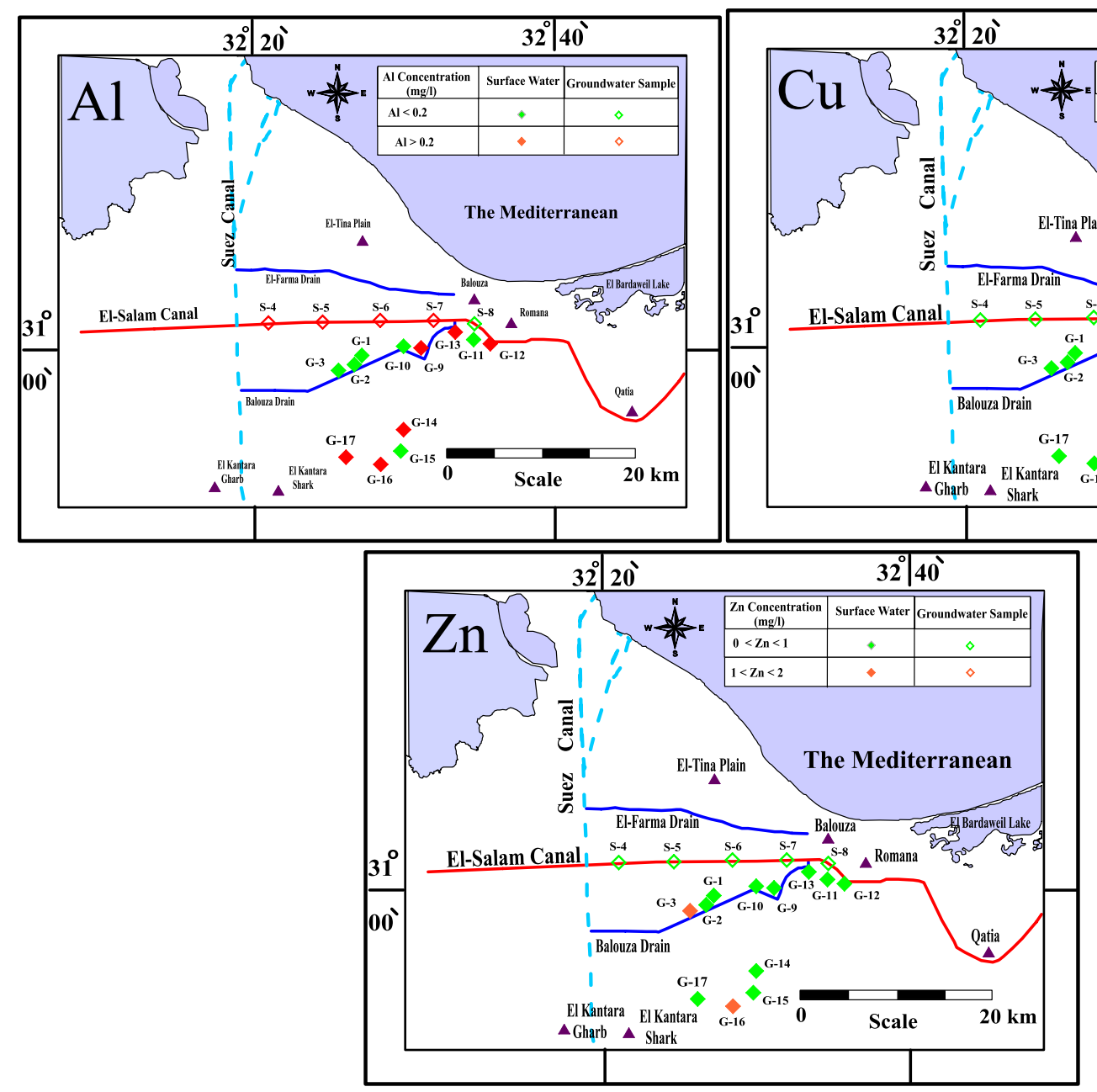

Fig. 7 Distribution of $\mathrm{Al}, \mathrm{Cu}$ and $\mathrm{Zn}$ in surface and groundwater adjacent to El-Salam Canal 
Table 2 Recommended standard limits for drinking and irrigation water

\begin{tabular}{lll}
\hline Metal & $\begin{array}{l}\text { Standard limit for drinking } \\
(\mathrm{mg} / \mathrm{l}) \\
(\mathrm{WHO} 2007)\end{array}$ & $\begin{array}{l}\text { Standard limit for } \\
\text { irrigation }(\mathrm{mg} / \mathrm{l}) \\
(\text { AWG 2012) }\end{array}$ \\
\hline $\mathrm{Al}$ & 0.2 & 5 \\
$\mathrm{Cu}$ & 1 & 0.2 \\
$\mathrm{Zn}$ & 3 & 2 \\
\hline
\end{tabular}

water of El-Salam and the adjacent groundwater were close to these ranges.

Effect of contact time and initial concentration The effect of both contact time and different initial concentrations was studied through plotting the adsorbed metal capacity $\left(q_{t}\right)$ versus the time ( $t$ ) for $\mathrm{Al}(\mathrm{III}), \mathrm{Cu}(\mathrm{II})$ and $\mathrm{Zn}(\mathrm{II})$ and the removal efficiency with time in Fig. 9c-e, respectively. The adsorption reached equilibrium for $\mathrm{Cu}$ (II) and $\mathrm{Zn}$ (II) within $20 \mathrm{~min}$ and within $30 \mathrm{~min}$ for $\mathrm{Al}(\mathrm{III})$. The total amount of adsorbed metals increased as the initial concentrations increased.

The removal process took place in two steps. In the first step, the heavy metal was removed fast (occurred within $5 \mathrm{~min}$ for $\mathrm{Zn}$ (II) and $\mathrm{Cu}$ (II) and $10 \mathrm{~min}$ for $\mathrm{Al}(\mathrm{III})$ ), but in the second step it happened slowly and exhibited a subsequent removal until equilibrium was reached. The main reason for the appearance of the rapid step was the plenty-free adsorptive active sites on the MZNCs at the first stages of adsorption process, while gradual occupancy of these sites resulted in the emergence of the slower adsorption step. At the next step, the uptake rate decreased as it was controlled by the rate at which the ions were transported from the exterior to the interior sites of the adsorbent. It also decreased due to aggregation of metal ions around MZNCs. This aggregation may hamper the migration of the adsorbate, as the adsorption sites become filled up. In addition, resistance to the diffusion of metal ions in the adsorbents increases (Mittal et al. 2010).

\section{Adsorption kinetics}

In order to determine and interpret the mechanisms of metal adsorption processes and the main parameters governing adsorption kinetics, several kinetic models are proposed, like pseudo-first order and pseudo-second order. The linear plots of $\ln \left(q_{e}-q_{t}\right)$ versus $t$ and $t / q_{t}$ versus $t$ are depicted in Fig. 10a, b for adsorption of $\mathrm{Al}(\mathrm{III}), \mathrm{Cu}(\mathrm{II})$ and $\mathrm{Zn}$ (II) using MZNCs, respectively. $k_{1}, k_{2}$ and $q_{e}$ calculated from the slopes and intercepts of the lines are listed in Table 3 for $\mathrm{Al}(\mathrm{III}), \mathrm{Cu}(\mathrm{II})$ and $\mathrm{Zn}(\mathrm{II})$, respectively. As it can be seen, comparing the correlation coefficients $\left(R^{2}\right)$, the pseudosecond-order model fits better the adsorption kinetics of
$\mathrm{Al}(\mathrm{III}), \mathrm{Cu}(\mathrm{II})$ and $\mathrm{Zn}(\mathrm{II})$ on MZNCs than the pseudo-firstorder model.

The value of the correlation coefficients $\left(R^{2}\right)$ and agreement of calculated $\mathrm{q}_{\mathrm{t}}$ with experimental data revealed that sorption process can be described well by the pseudo-second-order equation. The rate of ion exchange process is governed by film diffusion, particle diffusion or chemical exchange (chemisorptions). It is reported that the rate of ion exchange is controlled by chemical exchange if experimental data are fitted to pseudo-second-order equation. Therefore, the overall rate constant of both sorption process appears to be controlled by the chemical sorption process.

Pseudo-second-order fit well with correlation coefficient values more than 0.99 for $\mathrm{Al}(\mathrm{III}), \mathrm{Cu}$ (II) and $\mathrm{Zn}$ (II) adsorption. This result indicated that this sorption system is a pseudo-second-order reaction, implying that the adsorption mechanism depended on the adsorbate and adsorbent, and the rate-limiting step may be a chemical sorption involving valence forces through sharing or exchanging of electrons. The values of calculated equilibrium capacities $\left(q_{e}\right.$-estimated) from the pseudo-second order were almost in accordance with those of experimental capacities $\left(q_{e}\right.$-experimental $)$ at different initial $\mathrm{Al}(\mathrm{III}), \mathrm{Cu}(\mathrm{II})$ and $\mathrm{Zn}(\mathrm{II})$ concentrations.

A higher metal adsorption rate was observed for low initial metal concentrations, which could be due to the presence of more active sites that are available on the MZNCs surface. As the active sites are exhausted, rate of the uptake may be decreased. The low value of rate constant $\left(K_{2}\right)$ showed that the adsorption rate decreased with the increase in time and the adsorption rate was proportional to the number of unoccupied sites.

\section{Adsorption isotherms}

Equilibrium adsorption isotherms (capacity studies) are of fundamental importance in the design of adsorption systems since they indicate how metal ions are partitioned between the adsorbent and liquid phases at equilibrium as a function of metal concentrations. When an adsorbent comes into contact with a metal ions solution, the concentration of metal ions on the surface of the adsorbent will increase until a dynamic equilibrium is reached. At this point, there is a clearly defined distribution of metal ions between the solid and liquid phases. The most widely used adsorption isotherms are the Langmuir model and the Freundlich model. Figure $11 \mathrm{a}-\mathrm{f}$ shows the fitting of these isotherms for $\mathrm{Al}(\mathrm{III})$ $\mathrm{Cu}(\mathrm{II})$ and $\mathrm{Zn}$ (II) adsorption by MZNCs, respectively. The model parameters and statistical fits of the sorption data are given in Table 4. Based on equilibrium concentration $C_{\mathrm{e}}$ in solution and adsorbed amount of heavy metal on MZNCs at equilibrium $\mathrm{q}_{\mathrm{e}}$, a linear plot was obtained when $C_{\mathrm{e}} / q_{\mathrm{e}}$ was plotted against $C_{\mathrm{e}}$ over the entire concentration range from 10 to $100 \mathrm{ppm}$ of metal ions. The linearized Langmuir 

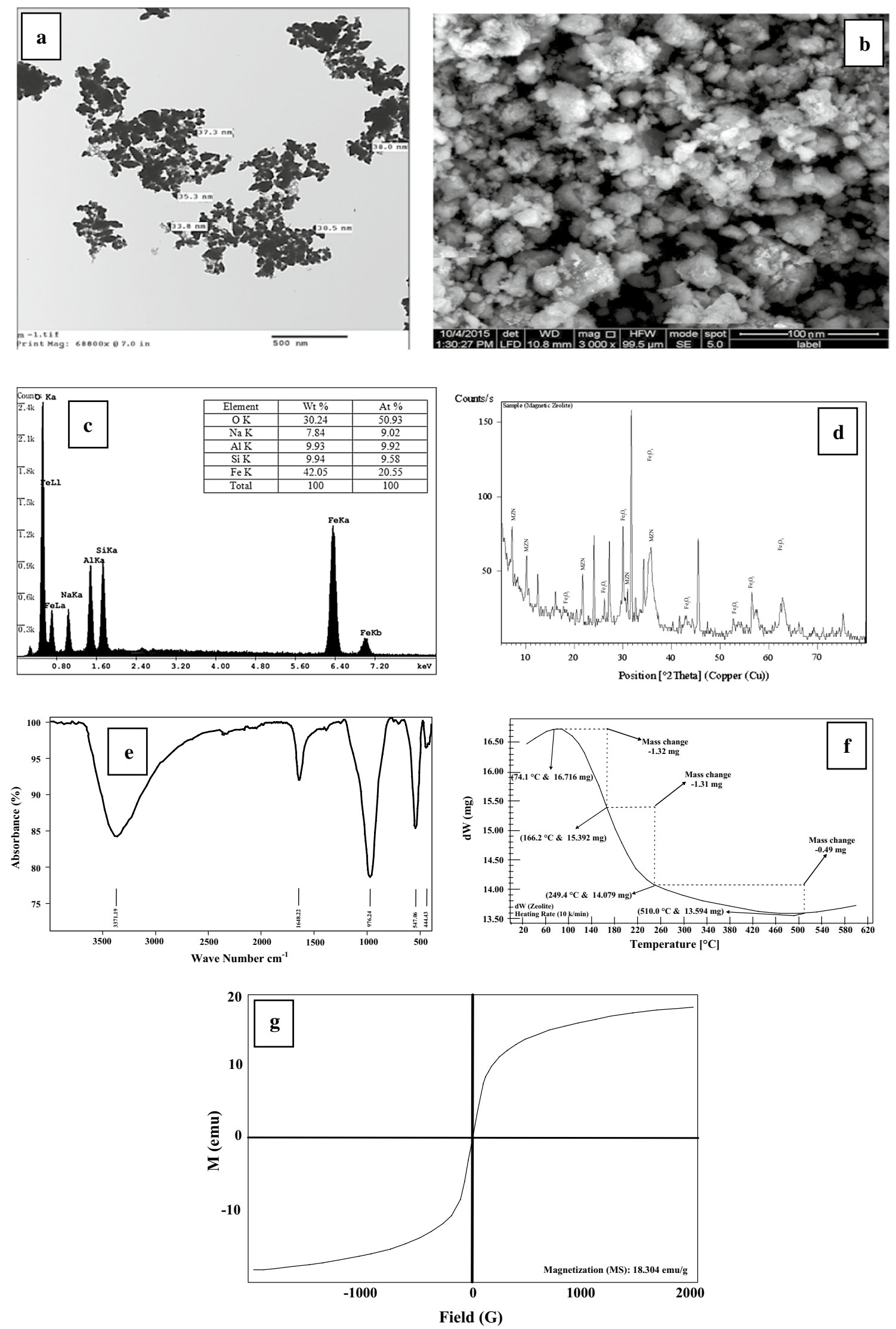
4Fig. 8 Characterization of magnetic zeolite composite (MZCs). a TEM image of MZNCs, $\mathbf{b}$ SEM image of MZNCs, $\mathbf{c}$ EDX of MZNCs and $\mathbf{d}$ XRD pattern for MZNCs, e FTIR spectrum of MZNCs, $\mathbf{f}$ TGA curve of MZNCs and $\mathbf{g}$ VSM curve of MZNCs

adsorption isotherm of $\mathrm{Al}(\mathrm{III}), \mathrm{Cu}$ (II) and $\mathrm{Zn}$ (II) ions is given in Fig. 11a-f, respectively. The model parameters $\left(K_{1}\right.$,
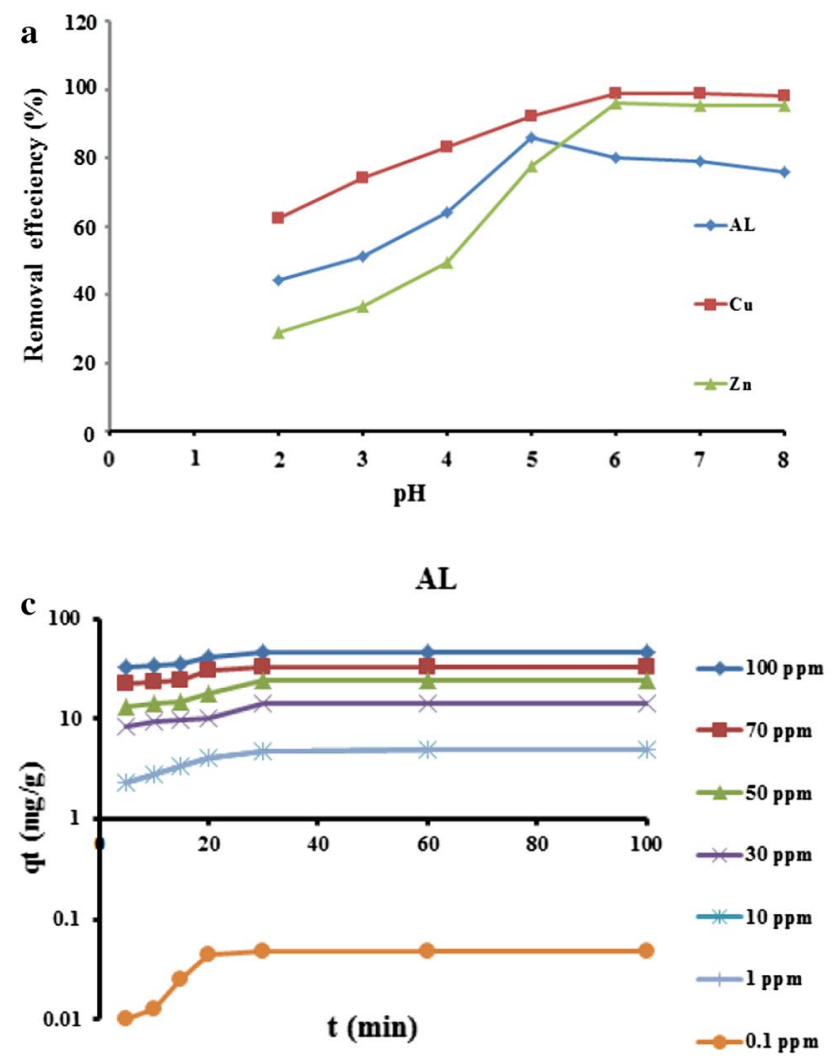

$R_{\mathrm{L}}$ ) and statistical fits of the sorption data to this equation are given in Table 4.

From both Langmuir and Freundlich isotherms, we propose the adsorption as a chemical sorption between $\mathrm{Al}$ (III), $\mathrm{Cu}(\mathrm{II})$ and $\mathrm{Zn}$ (II) and MZNCs and physical adsorption between the negative surface charge of amphoteric MZNCs and positive ions of $\mathrm{Al}(\mathrm{III}), \mathrm{Cu}$ (II) and $\mathrm{Zn}$ (II). The Langmuir
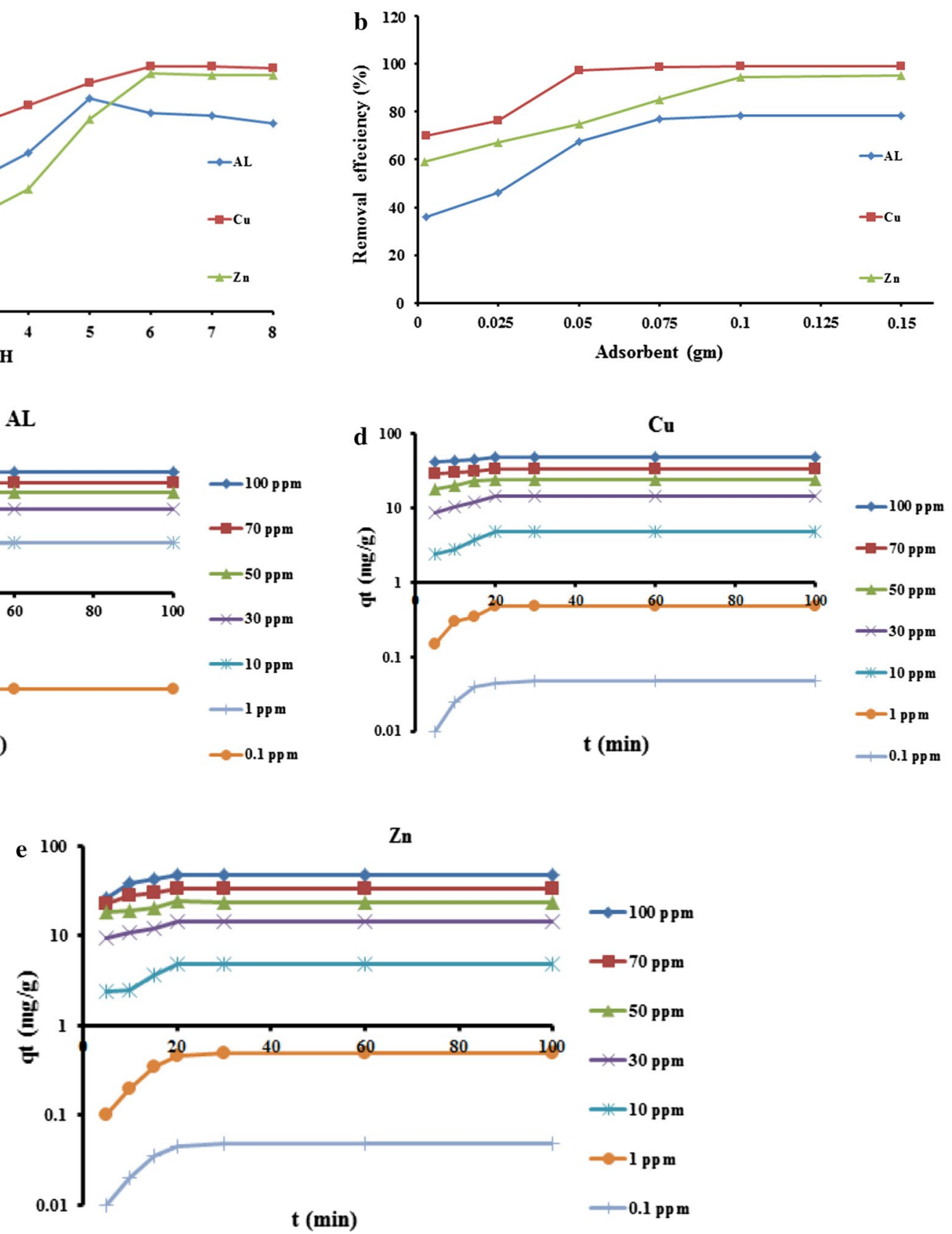

Fig. 9 Removal efficiency of $\mathrm{Al}(\mathrm{III}), \mathrm{Cu}(\mathrm{II})$ and $\mathrm{Zn}$ (II) on MZNCs. a Different $\mathrm{pH}$ values (100 ppm each, $0.1 \mathrm{~g}$ MZNCs, $24 \mathrm{~h}, 50 \mathrm{ml})$; b different adsorbent mass (100 ppm each, ambient pH, 24 h, $50 \mathrm{ml}$ ); c adsorption of $\mathrm{Al}(\mathrm{III})$ in solution with different initial concentrations at $\mathrm{pH}=5$ and $27^{\circ} \mathrm{C} ; \mathbf{d}$ adsorption of $\mathrm{Cu}(\mathrm{II})$ in solution with different initial concentrations at $\mathrm{pH}=6$ and $27{ }^{\circ} \mathrm{C}$; e adsorption of $\mathrm{Zn}$ (II) in solution with different initial concentrations at $\mathrm{pH}=6$ and $27^{\circ} \mathrm{C}$ 

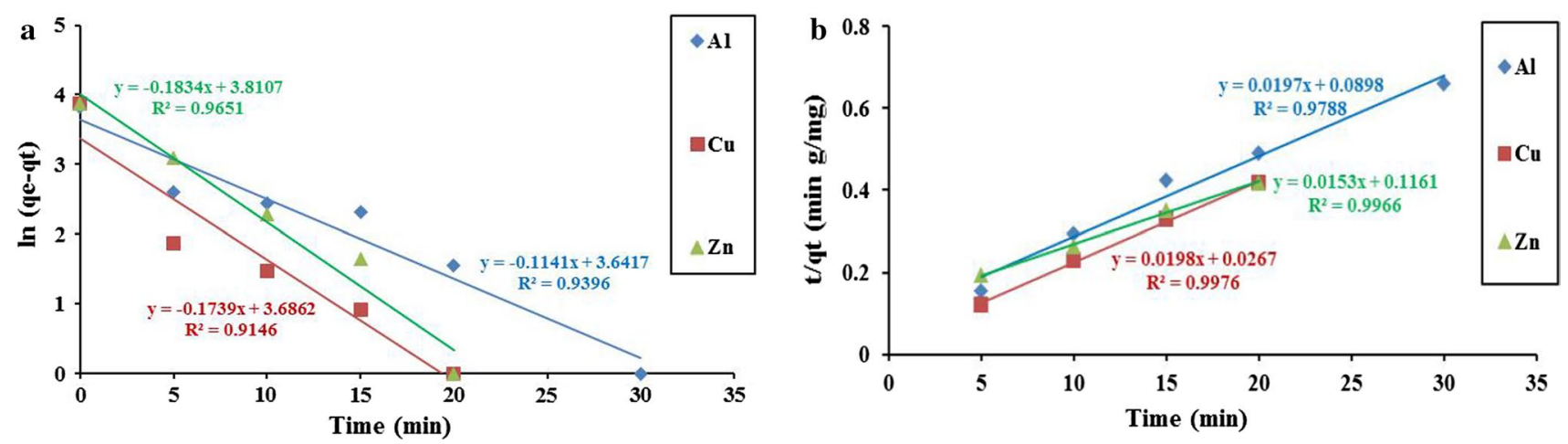

Fig. 10 a Pseudo-first-order plot of $\mathrm{Al}(\mathrm{III}), \mathrm{Cu}(\mathrm{II})$ and $\mathrm{Zn}(\mathrm{II})$ adsorption by $\mathrm{MZNCs}$ at $\mathrm{pH}=5$ for $(\mathrm{Al}), \mathrm{pH}=6$ for $(\mathrm{Cu}$ and $\mathrm{Zn})$ and $27{ }^{\circ} \mathrm{C}$. b Pseudo-second-order plot of $\mathrm{Al}(\mathrm{III}), \mathrm{Cu}(\mathrm{II})$ and $\mathrm{Zn}(\mathrm{II})$ adsorption by $\mathrm{MZNCs}$ at $\mathrm{pH}=5$ for (Al), $\mathrm{pH}=6$ for $(\mathrm{Cu}$ and $\mathrm{Zn})$ and $27^{\circ} \mathrm{C}$

model parameters effectively described the sorption data of $\mathrm{Al}(\mathrm{III}), \mathrm{Cu}(\mathrm{II})$ and $\mathrm{Zn}(\mathrm{II})$ with $0.958,0.9653$ and 0.9908 correlation coefficient $\left(R^{2}\right)$ for $\mathrm{Al}(\mathrm{III}), \mathrm{Cu}(\mathrm{II})$ and $\mathrm{Zn}(\mathrm{II})$, respectively. Based on equilibrium concentration $C_{\mathrm{e}}$ in solution and adsorbed amount of heavy metal on MZNCs at equilibrium $q_{e}$, a linear plot was obtained when $\log q_{e}$ was plotted against $\log C_{\mathrm{e}}$ over the entire concentration range of metal ions. The linearized Freundlich adsorption isotherm of $\mathrm{Al}(\mathrm{III}), \mathrm{Cu}(\mathrm{II})$ and $\mathrm{Zn}(\mathrm{II})$ ions is given in Fig. 11a-f, respectively. Freundlich constants $k_{f}$ and $n$ were calculated for each cation and are illustrated in Table 4. $R_{\mathrm{L}}$ constant for $\mathrm{Al}(\mathrm{III}), \mathrm{Cu}(\mathrm{II})$ and $\mathrm{Zn}$ (II) is $0.0101,0.011$ and 0.0163 , respectively. It is less than unity that confirms that the adsorption reaction follows Langmuir. The $R_{\mathrm{L}}$ values are within the interval $\left(0<R_{\mathrm{L}}<1\right)$, thus confirming the adsorption favorability (Liu 2006).

However, Freundlich isotherm fits the experimental adsorption data of $\mathrm{Al}(\mathrm{III}), \mathrm{Cu}$ (II) and $\mathrm{Zn}$ (II) cations over a wide range of concentrations, with better adjustment than Langmuir isotherm with $0.9714,0.9974$ and 0.9998 correlation coefficient $\left(R^{2}\right)$ for $\mathrm{Al}(\mathrm{III}), \mathrm{Cu}(\mathrm{II})$ and $\mathrm{Zn}(\mathrm{II})$, respectively. This isotherm gave an expression encompassing the surface heterogeneity and the exponential distribution of active sites and their energies with multilayer physisorption which is not restricted to monolayer formations (Shalaby et al. 2017).

\section{Conclusion}

The chemistry of El-Salam Canal varies greatly, where the water salinity increases from the western toward the eastern side. Additionally, the main factor controlling the groundwater chemistry tapping the Quaternary aquifer is the dilution effect from El-Salam Canal water. The results show lower groundwater salinity close to Baloza drain due to surface water groundwater interaction. The heavy metals reveal higher concentration in El-Salam Canal surface water as well as in the adjacent groundwater. Therefore, the water treatment is crucial to meet the continuous demand of water supply, specifically in arid regions. In most surface and groundwater samples, the concentrations of $\mathrm{Al}(\mathrm{III}), \mathrm{Cu}$ (II) and $\mathrm{Zn}(\mathrm{II})$ exceeded the recommended international standard for drinking and short-term irrigation. The magnetic zeolite nanocomposite successfully synthesized through the co-precipitation of $\mathrm{Fe}^{3+}$ and $\mathrm{Fe}^{2+}$ in the presence of zeolite. XRD study revealed the crystal nature of MZNCs with cubic spinel structure, indicating high-crystalline structure form. The TGA indicates great stability of MNPs at higher temperatures. The results show that MZNCs have good super-paramagnetic properties; when external MF is removed, the MZNCs can be redispersed quickly with shaking. The saturation magnetization value of magnetic zeolite was $18.3 \mathrm{emu} / \mathrm{g}$ which confirms that in practice, the composite can be easily separated with a permanent magnet. The MZNCs show great removal capacity of heavy metals where $0.1 \mathrm{~g}$ is able to clean contaminated water with

Table 3 Kinetics parameters for the adsorption of $\mathrm{Al}(\mathrm{III}), \mathrm{Cu}$ (II) and $\mathrm{Zn}(\mathrm{II})$ on $\mathrm{MZNCs}$ at $\mathrm{pH}=5$ for $(\mathrm{Al}), \mathrm{pH}=6$ for $(\mathrm{Cu}$ and $\mathrm{Zn})$ and $27^{\circ} \mathrm{C}$

\begin{tabular}{lccc}
\hline & $\mathrm{Al}(\mathrm{III})$ & $\mathrm{Cu}(\mathrm{II})$ & $\mathrm{Zn}(\mathrm{II})$ \\
\hline Pseudo-first-order & & & \\
$R^{2}$ & 0.9396 & 0.9146 & 0.9651 \\
$q_{e \text {-estimated }}(\mathrm{mg} / \mathrm{g})$ & 38.1566 & 39.89 & 45.182 \\
$q_{e \text {-experimental }}(\mathrm{mg} / \mathrm{g})$ & 45.4985 & 48.001 & 47.75 \\
$K_{1}\left(\mathrm{~min}^{-1}\right)$ & 0.1141 & 0.1739 & 0.1834 \\
Pseudo-second-order & & & \\
$R^{2}$ & 0.9788 & 0.9976 & 0.9966 \\
$q_{e \text {-estimated }}(\mathrm{mg} / \mathrm{g})$ & 50.76 & 50.50 & 55.35 \\
$q_{e \text {-experimental }}(\mathrm{mg} / \mathrm{g})$ & 45.49 & 48.001 & 47.75 \\
$K_{2}\left(\mathrm{~g} \mathrm{mg}^{-1} \mathrm{~min}^{-1}\right)$ & 0.004 & 0.015 & 0.0020 \\
\hline
\end{tabular}




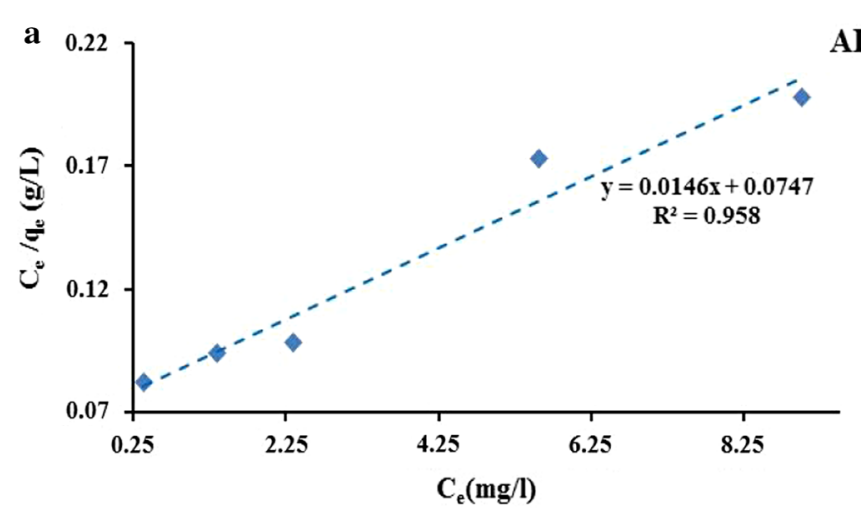

b

$\mathbf{A L}$
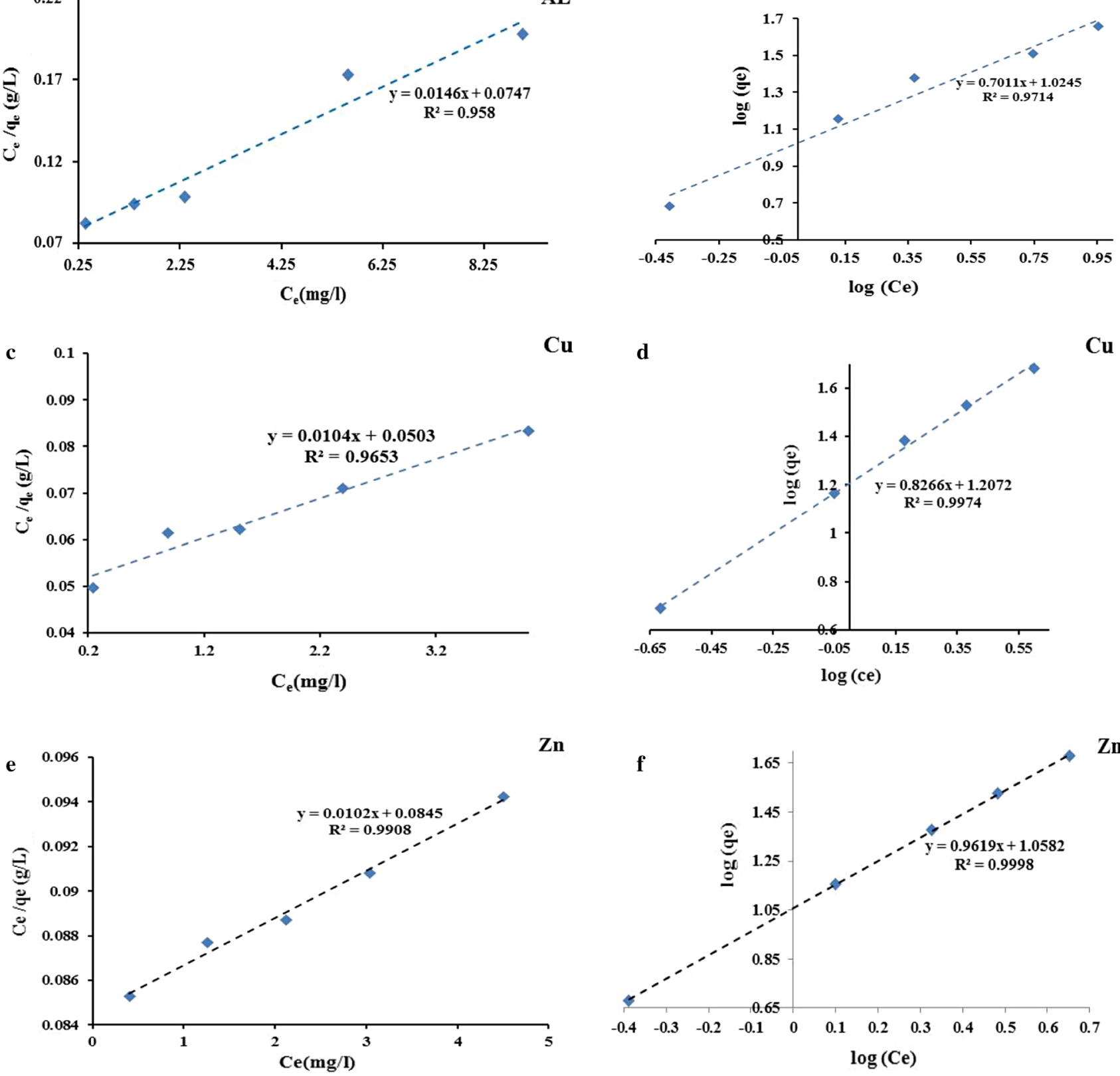

Fig. 11 a Langmuir isotherm for the adsorption of $\mathrm{Al}(\mathrm{III})$ by MZNCs; b Freundlich isotherm for the adsorption of $\mathrm{Al}(\mathrm{III})$ by MZNCs; c Langmuir isotherm for the adsorption of $\mathrm{Cu}(\mathrm{II})$ by MZNCs; d Freundlich isotherm for the adsorption of $\mathrm{Cu}(\mathrm{II})$ by

high concentrations $(0.5-3 \mathrm{~g} / \mathrm{l})$ of $\mathrm{Cu}(\mathrm{II})$ and $\mathrm{Zn}(\mathrm{II})$ within $20 \mathrm{~min}$, while for $\mathrm{Al}(\mathrm{III})$ within $30 \mathrm{~min}$. The Langmuir model parameters effectively described the sorption data of $\mathrm{Al}(\mathrm{III}), \mathrm{Cu}(\mathrm{II})$ and $\mathrm{Zn}(\mathrm{II})$ with $0.958,0.9653$ and 0.9908 correlation coefficient $\left(R^{2}\right)$ for $\mathrm{Al}(\mathrm{III}), \mathrm{Cu}(\mathrm{II})$ and $\mathrm{Zn}(\mathrm{II})$, respectively. But Freundlich isotherm fits the experimental
$\mathrm{Cu}$

d

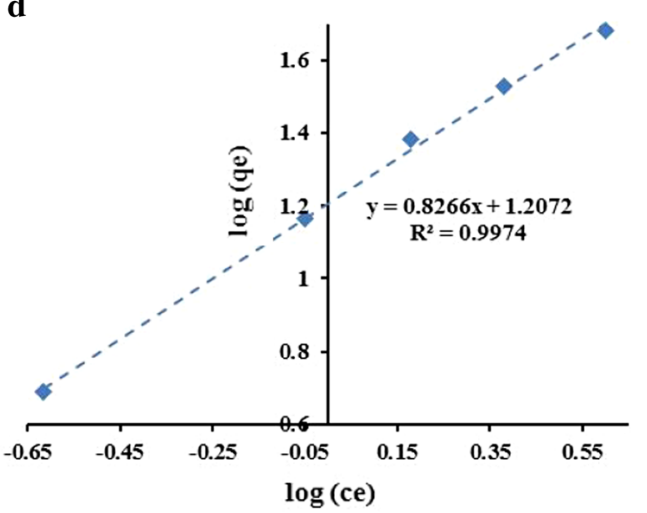

$\mathrm{Cu}$

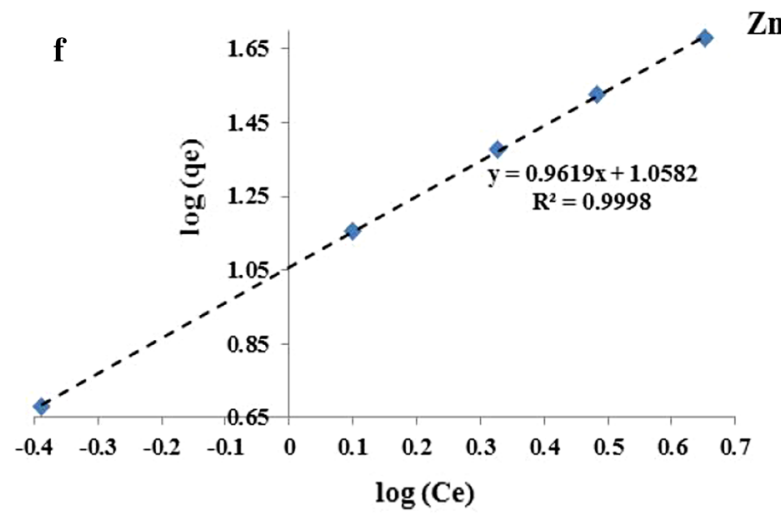

MZNCs; e Langmuir isotherm for the adsorption of $\mathrm{Zn}(\mathrm{II})$ by MZNCs; and $\mathbf{f}$ Freundlich isotherm for the adsorption of $\mathrm{Zn}$ (II) by MZNCs

adsorption data of $\mathrm{Al}(\mathrm{III}), \mathrm{Cu}(\mathrm{II})$ and $\mathrm{Zn}(\mathrm{II})$ cations over a wide range of concentrations with better adjustment than Langmuir isotherm with $0.9714,0.9974$ and 0.9998 correlation coefficient $\left(R^{2}\right)$ for $\mathrm{Al}(\mathrm{III}), \mathrm{Cu}(\mathrm{II})$ and $\mathrm{Zn}(\mathrm{II})$, respectively. These experiments demonstrate that the MZNCs can significantly be used efficiently in the removal of heavy metals and has very good results in water treatment. 
Table 4 Isotherm constants for the adsorption of $\mathrm{Al}(\mathrm{III}), \mathrm{Cu}(\mathrm{II})$ and $\mathrm{Zn}(\mathrm{II})$ on MZNCs at $\mathrm{pH}=5$ for $(\mathrm{Al}), \mathrm{pH}=6$ for $(\mathrm{Cu}$ and $\mathrm{Zn})$ and $27{ }^{\circ} \mathrm{C}$

\begin{tabular}{lccc}
\hline & $\mathrm{Al}(\mathrm{III})$ & $\mathrm{Cu}(\mathrm{II})$ & $\mathrm{Zn}(\mathrm{II})$ \\
\hline Langmuir isotherm & & & \\
$R^{2}$ & 0.958 & 0.9653 & 0.9908 \\
$q_{m}(\mathrm{mg} / \mathrm{g})$ & 68.49 & 96.15 & 98.04 \\
$K_{\mathrm{l}}(\mathrm{l} / \mathrm{mg})$ & 0.1954 & 0.2067 & 0.1207 \\
$R_{\mathrm{L}}$ & 0.0101 & 0.011 & 0.0163 \\
Freundlich isotherm & & & \\
$R^{2}$ & 0.9714 & 0.9974 & 0.9998 \\
$K_{\mathrm{f}}(1 / \mathrm{mg})$ & 1.2738 & 6.5734 & 1.7606 \\
$n$ & 1.426 & 1.211 & 1.041 \\
\hline
\end{tabular}

Acknowledgements The authors gratefully acknowledge the Science and Technology Development Funding (STDF) of Egypt for providing facilities and supportive funding through Project \# 5821. The authors also thank L. Craig for assisting with the edits and language.

Open Access This article is distributed under the terms of the Creative Commons Attribution 4.0 International License (http://creativeco mmons.org/licenses/by/4.0/), which permits unrestricted use, distribution, and reproduction in any medium, provided you give appropriate credit to the original author(s) and the source, provide a link to the Creative Commons license, and indicate if changes were made.

\section{References}

Abdel Baky TE (2001) Heavy metals concentrations in the cat fish Claries gariepinus from River Nile, El-Salam Canal and Lake Manzala and their impact on cortisol and thyroid hormones, Egypt. J Aquat Biol Fish 5(1):79-98

Ahmed MG (2003) Water quality management for El-Salam canal. M.Sc. Thesis, Cairo University, Giza, Egypt

AWG (2012) Australian Water Guidelines for irrigation, the State of Queensland. Department of Environment and Heritage Protection. https://www.ehp.qld.gov.au/water/guidelines/, 2012-2018

Bonilla A, Baudouin D, Pérez-Ramírez J (2009) Desilication of ferrierite zeolite for porosity generation and improved effectiveness in polyethylene pyrolysis. J Catal 265:170-180

Drainage Research Institute (DRI) (1993) Drainage water. Volume III. Drainage Water Reuse Project

Desert Research Center (DRC) (2009) Sustainable agricultural development studies of El-Salam Canal, STDF final internal project report, DRC library, Cairo, Egypt

El Sheikh A, El Osta M, El Sabri M (2013) Study of the phenomenon of groundwater levels rise in south El Qantara Shark area, Ismailia, Egypt. Hydrogeol Hydrol Eng J 2:2

El-Degwi AM, Abdelsatar A, Gawad ST, Gawad SM (2004) Variation of BOD pollution rate within Hadous Drain Catchments of Egypt. In: 2nd ICID Asian Conference on Irrigation and Drainage, Moama, 14-17 March, pp 14-26

El-Naggar MM, Hagras AE, Ogawa K, Hussein AB, El-Naggar AM (2000) A correlation between heavy metals in water and gills of Oreochromis niloticus and Tilapia zillii and the intensity of their parasitic monogeneans at Manzala Lake and the River Nile in Egypt. J Egypt Ger Soc Zool 32(D):189-204
Embaby AA, El-Barbary SA (2011) Evaluation of Quaternary aquifer for agricultural purposes in northwest Sinai, Egypt. J Am Sci 7(3):344-361

Faghihian HM, Moayed A, Iravani M (2014) Evaluation of a new magnetic zeolite composite for removal of $\mathrm{Cs}^{+}$and $\mathrm{Sr}^{2+}$ from aqueous solutions: kinetic, equilibrium and thermodynamic studies. C R Chim 17(2014):108-117

Fishman MJ, Friedman LC (1985) Methods for determination of inorganic substances in water and fluvial sediments, U.S. Geological Survey Book 5, Chapter A1. Open File Report 84:85-495 Denver Colorado U.S.A. for hydrogen isotope analysis. Anal Chem 63:910-912

Godfray HC, Beddington JR, Crute IR, Haddad L, Lawrence D, Muir JF (2010) Food security: the challenge of feeding 9 billion people. Science 327:812-818

Hafeza A, Khedra M, El-Katiba K, Gad Allaa H, Elmanharawy S (2008) El-Salaam Canal project, Sinai II. Chemical water quality investigations. Desalination 227(2008):274-285

Hassan E (2015) Groundwater chemistry and its evolution in the northwestern portion of Sinai, Egypt. Ph.D. dissertation, Chemistry Department, Faculty of Science, Zagazig University 180 PA

Hem JD (1991) Study and interpretation of the chemical characteristics of natural water, 3rd edn. Scientific Publication, Jodhpur, p 2254

Hidayat R, Fadillah G, Chasanah U, Wahyuningsih S, Ramelan AR (2015) Effectiveness of urea nanofertilizer based amino propyl trimethoxysilane (APTMS)-zeolite as slow release fertilizer system. Afr J Agric Res 10:1785-1788

Ho YS, McKay G (1999) Pseudo-second order model for sorption processes. Process Biochem 34:451-465

Hu A, Apblett A (2014) Nanotechnology for water treatment and purification. Springer, Berlin

Jaishankar M, Mathew BB, Shah MS, Gowda KRS (2014) Biosorption of few heavy metal ions using agricultural wastes. J Environ Pollut Hum Health 2:1-6

Karge HG, Geidel E (2004) Vibrational spectroscopy. Mol Sieves 4:1-200. https://doi.org/10.1007/b94235

Lagergren S (1898) About the theory of so-called adsorption of soluble substances. Zurtheorie der sogenannten adsorption gelsterstoffe, Kungliga Svenska Vetenskapsakademiens, Handlingar 24:1-39

Lateef A, Nazir R, Jamil N, Alam S, Shah R, Khan MN, Saleem M (2016) Synthesis and characterization of zeolite-based nanocomposite: an environment-friendly slow release fertilizer. Microporous Mesoporous Mater 232:174-183

Liu Y (2006) Some consideration on the Langmuir isotherm equation. Colloids Surf A 274:34-36

Maity DC (2007) Agrawal. Mang Mang Mater 308:46

Mittal A, Mittal J, Malviya A, Gupta VK (2010) Removal and recovery of Chrysoidine $\mathrm{Y}$ from aqueous solutions by waste materials. J Colloid Interface Sci 344:497-507

Morais S, Costa FG, Pereira ML (2012) Heavy metals and human health. In: Oosthuizen J (ed) Environmental health-emerging issues and practice. InTech, Rijeka, pp 227-246

Morsy NAI (2014) Study of the water and salt balance of El-Salam Canal water in the area between El-Hesiniya plain and Balouza, Egypt. Ph.D. thesis, Ain Shams Univ

Musyoka NM, Petrik LF, Hums E, Kuhnt A, Schwieger W (2013) Thermal stability studies of zeolites A and X synthesized from South African coal fly ash. Res Chem Intermed. https://doi. org/10.1007/s11164-013-1211-3

Othman A, Rabeh S, Fayez M, Monib M, Hegazi N (2012) El-Salam canal is a potential project reusing the Nile Delta drainage water for Sinai desert agriculture: microbial and chemical water quality. Adv Res Cairo Univ J 3:99

Parmar M, Thakur LS (2013) Heavy metal Cu, Ni and Zn: toxicity, health hazards and their removal techniques by low-cost adsorbents: a short overview. Int J Plant Anim Environ Sci 3:143-157 
Piper AM (1953) A graphic procedure in the geochemical interpretation of water analysis. Am Geophys Union Trans 25(105):914-923

Quiñones I, Guiochon G (1996) Derivation and application of a Jovanovic-Freundlich isotherm model for single-component adsorption on heterogeneous surfaces. J Colloid Interface Sci 183:57-67

Rainwater FH, Thatcher LL (1960) Methods for collection and analysis of water samples. U.S. Geological Survey water supply, paper 1454. Washington: USGS

Salah El-Din TA, Elzatahry AA, Aldhayan DM, Al-Enizi AM, AlDeyab SS (2011) Synthesis and characterization of magnetite zeolite nano composite. Int J Electrochem Sci 6:6177-6183

Shalaby TI, El-Kady MF, Zaki AH, El-Kholy SM (2017) Preparation and application of magnetite nanoparticles immobilized on cellulose acetate nanofibers for lead removal from polluted water. Water Sci Technol Water Supply 17(1):176-187. https://doi. org/10.2166/ws.2016.124

Shannon MA, Bohn PW, Elimelech M, Georgiadis JG, Mariñas BJ, Mayes AM (2008) Science and technology for water purification in the coming decades. Nature 452:301-310

Smith JV, Pluth JJ, Artioli G, Ross FK (1984) Neutron and X-ray refinements of scolecite. In: Bisio A, Olson DH (eds) Proceedings of the 6th International Zeolite Conference. Butterworths, Guildford, pp $842-850$

\section{Affiliations}

\section{Thanaa Shalaby ${ }^{1} \cdot$ Mustafa Eissa $^{2}$ D $\cdot$ Marwa El Kady ${ }^{3} \cdot$ Suzan Abd El-Gaber $^{1}$}

1 Medical Biophysics Department, Medical Research Institute, Alexandria University, Alexandria, Egypt

2 Division of Water Resources and Arid Lands, Hydrogeochemistry Department, Desert Research Center, Cairo, Egypt
Stiff $H$ (1951) The interpretation of chemical water analysis by means of patterns. J Petroleum Technol 3(10):15-17

US Salinity laboratory staff (1954) Diagnosis and improvement of saline and alkali soils. U.S. Dept. Agri., handbook No. 60, Washington, DC

Usachev NY, Belanova EP, Krukovsky LM, Kanaev SA, Atalyan OK, Kazakov AV (2003) Thermal transformations in systems based on zeolites Y, X, and A containing zinc and sodium nitrates. Russ Chem Bull 52:1940-1949

World Health Organization (WHO) (2007) Guideline for drinking water quality. Recommendation vol. 4th ed. 36

Zamboulis D, Peleka EN, Lazaridis NK, Matis KA (2011) Metal ion separation and recovery from environmental sources using various flotation and sorption techniques. J Chem Technol Bio technol $86: 335-344$

Zhang W (2003) Nanoscale iron particles for environmental remediation: an overview. J Nanopart Res 5:323-332

Publisher's Note Springer Nature remains neutral with regard to jurisdictional claims in published maps and institutional affiliations.
3 City of Scientific Research and Technological Applications, New Borg El-Arab City, Egypt 